Portland State University

PDXScholar

6-10-1997

\title{
Effects of Orofacial Clefts on Early Career Maturity
}

JeannieKay McCall

Portland State University

Follow this and additional works at: https://pdxscholar.library.pdx.edu/open_access_etds

Part of the Speech and Hearing Science Commons

Let us know how access to this document benefits you.

\section{Recommended Citation}

McCall, JeannieKay, "Effects of Orofacial Clefts on Early Career Maturity" (1997). Dissertations and Theses. Paper 5407.

https://doi.org/10.15760/etd.7280

This Thesis is brought to you for free and open access. It has been accepted for inclusion in Dissertations and Theses by an authorized administrator of PDXScholar. Please contact us if we can make this document more accessible: pdxscholar@pdx.edu. 


\section{THESIS APPROVAL}

The abstract and thesis of JeannieKay McCall for the Master of Science in Speech

Communication: Speech and Hearing Sciences were presented July 10, 1997, and accepted by the thesis committee and the department.

COMMITTEE APPROVALS:

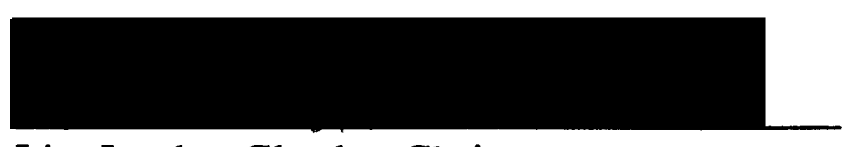

Lisa Letcher-Glembo, Chair

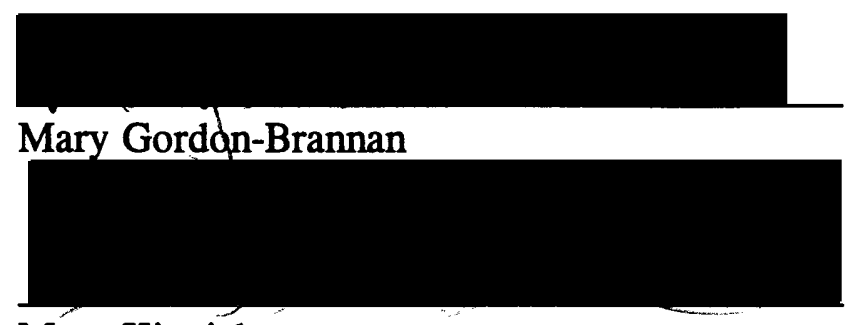

Mary Kinnick

Representative of the Office of Graduate Studies

DEPARTMENT APPROVAL:

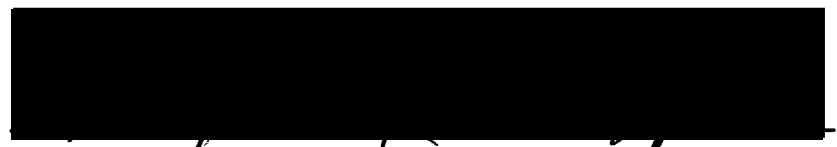

Stephen A! Kosokoff/ Chair

Department of Speech Communication

$* * * * * * * * * * * * * * * * * * * * * * * * * * * * * * * * * * * * * * * * * * * * * * * * * * * * * * * * * * * * * * * * * * * * *$

ACCEPTED FOR PORTLAND STATE UNIVERSITY BY THE LIBRARY

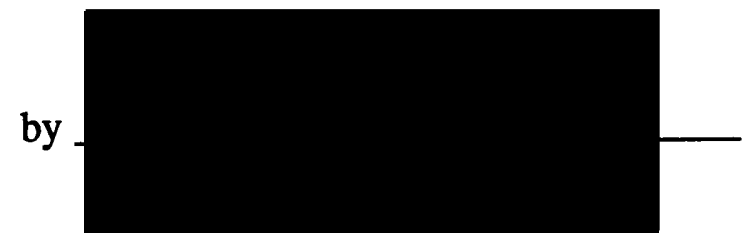

on

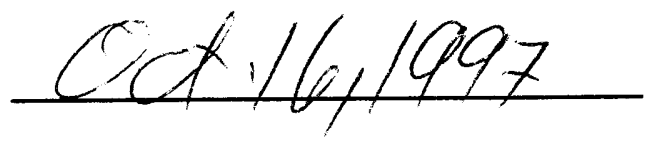




\begin{abstract}
An abstract of the thesis of JeannieKay McCall for the Master of Science in Speech Communication: Speech and Hearing Sciences presented July 10, 1997.
\end{abstract}

Title: Effects of Orofacial Clefts on Early Career Maturity

The purpose of this study was to investigate career maturity in 14- and 17year-old male and female adolescents with cleft lip and palate. Career maturity is defined as the repertoire of behaviors pertinent to identifying, choosing, planning, and executing career goals available to a specific individual as compared with those possessed by a peer group. Clefting is a congenital anomaly that occurs in approximately 1 in every 600 newborns and can result in facial scarring and speech deviations that may last throughout life, and may result in complications such as withdrawal, inhibition, lower self-esteem, and increasing self-doubt regarding interpersonal relationships. There is little research on the career development of adolescents with clefts.

This study included 19 adolescents with cleft lip and palate. All subjects completed measures of career development, self-concept, mental ability, and selfratings of speech and facial appearance. The study sought to determine: (a) if two 
age groups of male adolescents with clefts (14- and 17-year-olds) differ from two age groups of female adolescents with clefts (14- and 17-year-olds) in their level of career maturity; and (b) if two age groups of male adolescents with clefts (14- and 17-year-olds) differ from two age groups of female adolescents with clefts (14- an 17-year-olds) in factors related to career maturity. ANOVA analysis and Pearson $r$ Correlation Coefficient procedures were utilized to analyze data obtained.

A significant difference was found between the age groups; the 17-year-olds demonstrated higher levels of career maturity than did the 14-year-olds. While no statistically significant differences were found between the males and females, the data revealed that females scored higher in both age groups on the measure of career maturity. Mental ability was the factor that was most related to career maturity levels; self-concept showed a low relationship to career maturity. There was no evidence that the severity ratings on self-rating of facial appearance were related to their level of career maturity or their scores on other measures; however, the subjects' severity ratings on self-rating of speech were found to be correlated with level of self-concept scores. 
EFFECTS OF OROFACIAL CLEFTS ON

EARLY CAREER MATURITY

by

JEANNIEKAY MCCALL

A thesis submitted in partial fulfillment of the requirements for the degree of

\author{
MASTER OF SCIENCE \\ in \\ SPEECH COMMUNICATION: \\ SPEECH AND HEARING SCIENCES
}

Portland State University

1997 


\section{ACKNOWLEDGMENTS}

First I would like to thank my thesis advisor, Lisa Letcher-Glembo, for sharing her time and energy throughout the process of completing this project, as well as her knowledge in this select field of study. I also extend my appreciation to Mary Gordon- Brannan and Mary Kinnick for taking the time to read my thesis and providing insight and feedback.

A special thank you to both my parents and sister, who have provided endless encouragement from the beginning. Their encouragement and support have made it possible for me to fulfill my dreams. Many family and friends share a part of this process.

In addition, I want to thank Darrin for his much needed patience and understanding throughout the past three years. The many late hours of emergency computer advise and positive words of encouragement kept me sane throughout the development of this process. Now it is my turn to return the favor. 
TABLE OF CONTENTS

PAGE

ACKNOWLEDGMENTS $\ldots \ldots \ldots \ldots \ldots \ldots \ldots \ldots$ ii

LIST OF TABLES $\ldots \ldots \ldots \ldots \ldots \ldots \ldots \ldots \ldots \ldots$ vi

LIST OF FIGURES $\ldots \ldots \ldots \ldots \ldots \ldots \ldots \ldots \ldots \ldots \ldots \ldots$ viii

CHAPTER

I INTRODUCTION AND STATEMENT OF PURPOSE . . . . . . 1

Introduction $\ldots \ldots \ldots \ldots \ldots \ldots \ldots \ldots \ldots$

Statement of Purpose $\ldots \ldots \ldots \ldots \ldots \ldots \ldots \ldots$

Definition of Terms $\ldots \ldots \ldots \ldots \ldots \ldots$

II REVIEW OF THE LITERATURE $\ldots \ldots \ldots \ldots \ldots \ldots$

Career Maturity $\ldots \ldots \ldots \ldots \ldots \ldots \ldots$

Factors That Affect Career Maturity $\ldots \ldots \ldots \ldots \ldots$

Age and Grade Level $\ldots \ldots \ldots \ldots \ldots \ldots \ldots$

Gender . . . . . . . . . . . . . . . . 12

Mental Ability . . . . . . . . . . . . . . 13

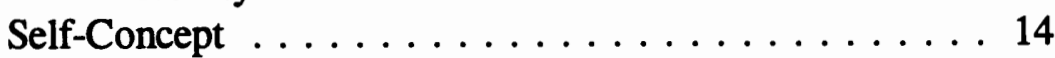

Special Populations . . . . . . . . . . . . . . . 15

Summary of the Factors That Affect Career Maturity . . 16

Factors That Affect the Psychosocial Functioning of

Adolescents With Clefts . . . . . . . . . . . 17

Effects of Facial Appearance on Behavior . . . . . . . 18

Effects of Speech Characteristics on Behavior . . . . . 22 
Summary: Factors That Affect the Psychosocial

Functioning of Adolescents with Clefts ...... 25

Effects of Orofacial Clefts on Career Development . . . . . 26

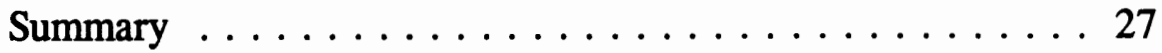

III METHODS ..................... 29

Subject Recruitment $\ldots \ldots \ldots \ldots \ldots \ldots \ldots$

Proposed Subject Sample Pool . . . . . . . . . . . 30

Identification and Recruitment of Cleft Subjects . . . . 30

Response Rate .................. 32

Subject Selection $\ldots \ldots \ldots \ldots \ldots \ldots \ldots \ldots \ldots \ldots$

Cleft Palate Subject Criteria . . . . . . . . . . 33

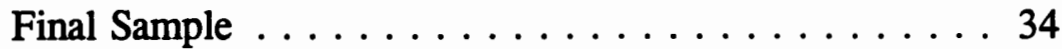

Measures and Procedures $\ldots \ldots \ldots \ldots \ldots \ldots \ldots$

Career Development Inventory . . . . . . . . . 35

Shipley Institute of Living Scale $\ldots \ldots \ldots \ldots . \ldots 37$

Biographical Questionnaire and Occupational Status

Scores ................ 38

Tennessee Self Concept Scale . . . . . . . . . . . 38

Self-Rating of Speech and Facial Acceptability . . . . . 39

Photographs .................. 39

Tape Recordings .............. 40

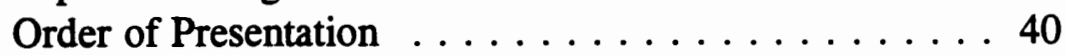

Data Analysis $\ldots \ldots \ldots \ldots \ldots \ldots \ldots \ldots \ldots$

IV RESULTS AND DISCUSSION $\ldots \ldots \ldots \ldots \ldots \ldots \ldots \ldots$

Results . . . . . . . . . . . . . . 43

Study Limitations . . . . . . . . . . . . . . . 43

Career Maturity Level Findings . . . . . . . . . . . 45

Mental Ability Findings . . . . . . . . . . . 48

Self-Concept Findings . . . . . . . . . . . . . . 49 
Self-Ratings of Speech and Facial Appearance

Findings ............... 51

Gender Effects on Career Maturity Level . . . . . . . 53

Age Effects on Career Maturity Level . . . . . . . . . 54

Combined Gender and Age Effects on Career Maturity . 55

Isolated Effects of Other Associated Factors on

Career Maturity Level . . . . . . . . . . . 57

Interaction Effects on Career Maturity Level . . . . . . 59

Discussion ...................661

V SUMMARY AND IMPLICATIONS $\ldots \ldots \ldots \ldots \ldots$

Summary $\ldots \ldots \ldots \ldots \ldots \ldots \ldots \ldots \ldots$

Implications $\ldots \ldots \ldots \ldots \ldots \ldots \ldots \ldots$

Clinical Implications . . . . . . . . . . . . 68

Future Research Implications . . . . . . . . . . . . 69

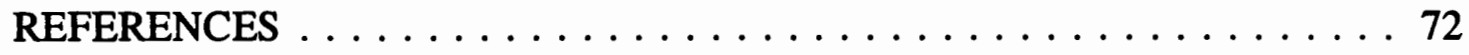

APPENDIXES

A Consent Form for Kaiser Permanente Subjects . . . . . . . . . 77

B Cover Letter for Oregon Health Sciences University Subjects . . . . 82

C Consent Form for Oregon Health Sciences University Subjects . . . 84

D Biographical Questionnaire $\ldots \ldots \ldots \ldots \ldots \ldots \ldots$

E Self-Ratings of Speech and Facial Appearance . . . . . . . 93

F Lazy Jack Reading Passage $\ldots \ldots \ldots \ldots \ldots \ldots \ldots$ 


\section{LIST OF TABLES}

TABLE

PAGE

1 Adolescents: Number of Subjects with Orofacial Clefting in Each Age and Gender Group . . . . . . . . . . . . . 34

2 Individual Male Subject Scores Across Study Measures . . . . . . . 46

3 Individual Female Subject Scores Across Study Measures . . . . . . 47

4 Least Squares Means for Gender on Career Orientation Total Standard Score ......................53

5 Gender Comparison to Career Orientation Total Standard Scores with Confidence Intervals of $95 \% \ldots \ldots \ldots \ldots \ldots$

6 Least Squares Means for Age on Career Orientation Total Standard Score ......................55

7 Age Comparison to Career Orientation Total Standard Scores with Confidence Intervals of $95 \% \ldots \ldots \ldots \ldots 5$

8 Two-Way ANOVA Summary for Effects of Age and Gender on Career Orientation Total Standard Scores . . . . . . . . . . . 56

9 Pearson Correlation Coefficients Between Career Orientation Total, Measures of Mental Ability (SILS), and Self-Concept

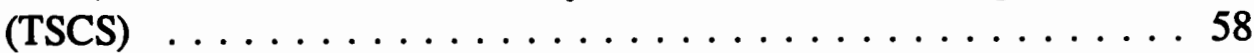

10 Two-Way ANOVA Summary for Effects of Age and Self-Rating of Speech on Career Orientation Total Standard Scores . . . . . . . 59

11 Two-Way ANOVA Summary for Effects of Age and Self-Rating of Facial Appearance on Career Orientation Total Standard Scores . . 59 
12 Two-Way ANOVA Summary for Effects of Age and Self-Rating of Speech and Self-Rating of Facial Appearance on Shipley Institute of Living Total Raw Scores . . . . . . . . . . . . . . . . . . 60

13 Four-Factor ANOVA Summary for Effects of Age, Gender, Self-Rating of Facial Appearance, and Self-Rating of Speech

Tennessee Self-Concept Scale Total Positive Raw Scores . . . . . . 61 


\section{LIST OF FIGURES}

FIGURE

PAGE

1 Shipley Institute of Living Mean $t$-scores for Male and Female Groups According to Age . . . . . . . . . . . . . . 49

2 Tennessee Self Concept Scale Mean $t$-scores for Male and

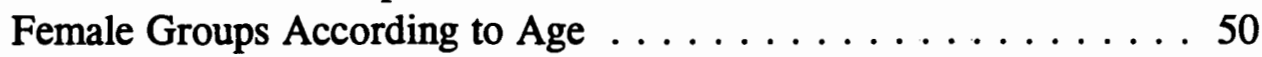

3 Self-Rating of Facial Appearance Mean Scores for Male and Female Groups According to Age . . . . . . . . . . . 52

4 Self-Rating of Speech Acceptability Mean Scores for Male and Female Groups According to Age . . . . . . . . . . 52

5 Career Orientation Total Mean Standard Scores for Male and Female Groups According to Age . . . . . . . . . . . 56 


\title{
CHAPTER I
}

\section{INTRODUCTION AND STATEMENT OF PURPOSE}

\author{
Introduction
}

Approximately 1 in every 600 newborns is born with the congenital anomaly of cleft lip and cleft palate (Moller, 1993). Individuals with cleft lip and palate may display differences in speech and appearance that last throughout their life, even years after treatment. These speech and appearance differences have important implications for children and adolescents, as it is a time when appearance and attractiveness is very important for development of normal social relationships and personality adjustment (Tobiasen, 1987). These differences may influence many aspects of life and result in complications such as social withdrawal, inhibition, lower self-esteem, and increasing self-doubt regarding interpersonal relationships (Harper \& Richman, 1978; Kapp, 1979; Richman, 1976; Richman \& Eliason, 1986). Most recent research has indicated that individuals' unrealistic perceptions of speech and facial appearance may contribute to these behavioral differences, particularly in terms of adjustment (Broder, Smith, \& Strauss, 1994; LetcherGlembo, 1989; Richman \& Eliason, 1986). These findings help us to understand the struggles of adolescents with cleft lip and/or palate, but do little to show how these 
differences impact the individual's behavior and future life experiences, such as career selection and development.

Career development has been studied in adolescents without clefts to determine factors that aid in career selection and future career satisfaction. Research has found that career development consists of a series of stages that begins in childhood. By adolescence, most individuals display a level of development that predicts one's future level of career satisfaction (Seligman, 1980). Tools have been designed to measure career maturity and can indicate the career development level at which an individual is functioning. Studies have revealed that adolescents' career maturity scores are predictive of later career satisfaction, and are related to their age, gender, self-concept, and mental ability grade (Herr \& Enderlein, 1976; Jordaan \& Heyde, 1979; Lawrence \& Brown, 1976; McNair \& Brown, 1983; Neely, 1980; Noeth \& Prediger, 1978; Pound, 1978; Super \& Thompson, 1979; Watson \& Van Aarde, 1986). Career maturity measures, utilized by professionals from a variety of disciplines, aid in determining what steps are needed to increase adolescents' level of career maturity, and therefore their future career fulfillment.

Deviations in speech and facial appearance and their effects on individuals' developmental process of career development are just beginning to be addressed. An earlier study by Letcher-Glembo (1989) investigated career development in a group of adolescents with cleft lip, cleft palate, and cleft lip and palate. Because all subjects with clefts did not necessarily demonstrate speech and facial differences, 
factors that affect career maturity may have been obscured. In order to further our understanding of the cleft lip/palate population, additional research is needed. Until then, our treatment of this population is dependent on our clinical instincts alone.

In order to serve children and adolescents with cleft lip and palate optimally, it is necessary to have information about the life outcomes of individuals with this type of congenital deformity. Prior to this, little research has focused on the longterm effects of orofacial clefting. This study adds to our limited data bank by providing clinicians with information about the career development of adolescents with clefts. Interestingly, at the last annual meeting of the American Cleft PalateCraniofacial Association, a call went out to the membership requesting data on the long-term outcome of individuals with craniofacial anomalies, such as clefting, on issues of employment rate, welfare use, and divorce figures (L. Letcher-Glembo, personal communication, June 20,1997$)$. Federal agencies want this information as they create health legislation and make funding decisions. These governmental groups want to know, "Is it worth spending our money to care for these special needs individuals in infancy and childhood? Will these same individuals develop to be productive, contributing members of society?" As members of the professional community, we currently cannot answer these questions with hard data. The current study is a step to remediate this problem. 


\section{Statement of Purpose}

The purpose of this study was to investigate the impact of orofacial clefting and related self-concept factors on the career maturity of a representative sample of male and female adolescents with clefts. Specifically, the following were investigated to determine which factors affect career maturity: age, gender, selfconcept, mental ability, facial appearance, and speech acceptability. Based on available literature, the following hypotheses are stated:

1. Female adolescents with clefts (14- and 17-year-olds) will demonstrate higher levels of career maturity than male adolescents with clefts (14- and 17-yearolds).

2. Seventeen-year-old adolescents with clefts (male and female) will demonstrate higher levels of career maturity than 14-year-old adolescents with clefts.

3. Individuals with high mental ability scores will demonstrate more advanced levels of career maturity, whereas individuals with lower mental ability scores will demonstrate more depressed levels of career maturity.

4. Individuals with more positive self-concept will demonstrate higher levels of career maturity while those with more negative self-concept will demonstrate more depressed levels of career maturity. Self-concept will be measured in global terms on a standardized test of self-concept as well as on more specific measures of self-rating of facial appearance acceptability and speech acceptability. 
The following research questions were asked:

1. Do two age groups of male adolescents with cleft lip and palate (14and 17-year-olds) differ from two age groups of female adolescents with cleft lip and palate (14- and 17-year-olds) in level of career maturity?

2. Do two age groups of male adolescents with cleft lip and palate (14and 17-year-olds) differ from two age groups of female adolescents with cleft lip and palate (14- and 17-year-olds) in factors thought to be related to career maturity? Potential factors include: mental ability, self-concept, self-rating of speech, and selfrating of facial appearance.

\section{Definition of Terms}

The following terms are defined as follows for the purposes of this study:

Career development: Career development has been defined as the total constellation of psychological, sociological, educational, physical, economic, and chance factors that combine to shape the career of any given individual (Herr \& Cramer, 1984).

Career Development Inventory (CDI): The CDI is a widely used test found useful in studies of career maturity (Thompson, Lindeman, Super, Jordaan, \& Meyers, 1981). There are high school and college versions of the CDI, each containing five individual scales and three composite scales. The individual scales 
are designed to provide information on career planning, career exploration, decisionmaking, world-of-work knowledge, and knowledge of preferred occupational group.

Career maturity: "The repertoire of behaviors pertinent to identifying, choosing, planning, and executing career goals available to an individual as compared with those possessed by an appropriate peer group" (Herr \& Cramer, 1984, p. 15).

Cleft stigmata: Differences that persist in individuals with clefts years after treatment; these differences include, but are not limited to: facial deformities, such as lip scarring, asymmetrical nares, and missing and/or maligned teeth; and speech deviations, such as articulation errors and hypernasality.

Facial acceptability: Social acceptance of the appearance of one's face; this social construct is important to the development of normal peer relationships, healthy personality, and success in school and in career, according to Tobiasen (1987).

Mental ability: The term that refers to a person's intelligence level.

Vocational self-concept: This construct is a vital part to Super's (1953) theory of vocational behavior; according to Super, vocational self-concept is part of one's total self-concept and is the driving force that helps establish one's career pattern throughout life; this construct develops through physical and mental growth, observations of work, identification with working adults, general environment, and general experiences (Zunker, 1990). 
Shipley Institute of Living Scale: A test that has been identified as a useful screening measure of estimating mental ability (Shipley, 1940; Revised by Zachary, 1987); the test consists of two subtests, a vocabulary test and an abstract thinking test and has shown to be a quick, accurate estimate of intellectual ability.

Tennessee Self Concept Scale (TSCS): A tool used to measure a person's selfconcept that consists of 100 self-descriptive statements, and the subject responds to the statements by choosing one of five responses, on a range from completely false to completely true (Fitts, 1965; 1991). 


\section{CHAPTER II}

\section{REVIEW OF THE LITERATURE}

Orofacial clefting is a congenital condition with associated speech and cosmetic deviations that typically persist throughout an individual's life. These deviations may produce behavioral differences that include increased inhibition, social withdrawal, and low self-concept. The factors that have been identified as having the greatest impact on career maturity levels are age, gender, mental ability, and self-concept. Currently, limited research is available on the effects of deviations, such as cleft lip and palate on career development. This study attempted to determine the career development of male and female adolescents with cleft lip and palate. The effects of factors, such as gender, age, self-perceived self-concept, and speech and facial appearance acceptability, on career development were targeted. Career maturity, its definition and implications, needs to be understood as do the factors that potentially affect career maturity. Measurement tools are reviewed and available literature findings on the impact of speech and facial deviations on the psychosocial status of persons with clefts are discussed. 


\section{Career Maturity}

Career development, according to Herr and Cramer (1984), is a lifelong process of growth and learning, which over time results in self-career identity, decision-making ability, and career maturity. This process involves psychological, sociological, educational, physical, economic, and chance factors and is known to occur in a series of stages. Individual self-concept, developmental experiences, personal history, and the psychosocial environment of the individual are important determinants that can assist in or hinder the acquisition of values, knowledge, and skills leading to competent career behavior (Herr \& Cramer, 1984).

The concept of career maturity was introduced about 40 years ago by Super (1957). Based on Super's theory of vocational development stages and vocational development tasks, a longitudinal research project was begun that followed the career development of about 300 ninth-grade boys over a period of 21 years (Super \& Overstreet, 1960). Tests, questionnaires, interviews, and school records were used to collect data when the subjects were $14,15,18,21,25$, and 36 years of age. The focus on this research project, known as the "Career Pattern Study," was on the concepts of career patterns, vocational life stages, vocational developmental tasks, and vocational maturity (Jordaan \& Heyde, 1979). According to Zunker (1990):

One of the major considerations of this study was to identify and validate the vocational developmental tasks relevant to each stage of development. Super thought that the completion of the appropriate tasks at each level was an indication of what he termed vocational maturity. (p. 34) 
The term vocational maturity was later replaced with the term career maturity. Since the Career Pattern Study, many studies have focused on factors that affect career maturity. Measurement tools have been designed to measure the level of career maturity in adolescents and young adults.

\section{Factors That Affect Career Maturity}

Studies of various subpopulations including white males, gifted high school students, and teens who are emotionally maladjusted have revealed variables that affect career maturity levels (Karayani, 1981; Super \& Overstreet, 1960). The following have been identified as major contributors: age and grade level, gender, mental ability, and self-concept. Findings for each are briefly reviewed.

\section{Age and Grade Level}

Due to the developmental nature of career behaviors over time, it seems reasonable to expect to find increases in career maturity as age and grade level increases. Noeth and Prediger (1978) found this to be true when they examined major components of career development across grades 8 to 12. The Assessment of Career Development (ACD) was given to an entire grade across four different high schools, representing four different geographic locations and community sizes. These students were retested at a 1-year interval and/or a 3-year interval. Eleven scales assessing different components of career development were used; cognitive and behavioral components were included. The results showed that career 
development systematically increases with age over the high school years.

Specifically, results indicated that students become more knowledgeable about career planning, seek out more information, and take part in more career exploration activities and demonstrate greater focus on their occupational preferences as they get older.

Herr and Enderlein (1976) similarly completed a longitudinal study over a period of several years by following 1,553 high school students from ninth grade into their post-secondary school careers. The authors used the Career Maturity Inventory (CMI) (Crites, 1978) to measure the students' level of career maturity. The results demonstrated that career maturity increases with age. Although the three samples in this study found that at the end of the 12th grade all subjects seem to reach the same point of career maturity, the authors discovered that school differences, curriculum effects, and sex differences influenced the rate and level of vocational maturity that occurs.

The Career Development Inventory (CDI) (Thompson et al. 1981) was given to 600 ninth-graders and 40011 th-graders by Super and Thompson (1979). As they expected, the CDI scores were developmental in nature; scores were significantly higher for the 11th-graders then the ninth-graders. These developmental increases in age and grade have been found in urban settings (Herr \& Enderlein, 1976; Super \& Thompson, 1979), rural settings (Herr \& Enderlein, 1976; Noeth \& Prediger, 1978), 
suburban settings (Noeth \& Prediger, 1978; Super \& Thompson, 1979), and different ethnic groups (Dillard \& Perrin, 1980).

\section{Gender}

One of the shortcomings of the Career Pattern Study (CPS) was the absence of women from the study. The CPS was begun at a time when women's work histories tended to be brief, due to marriage and homemaking; and because the study was longitudinal, spanning over 21 years, it was decided to permit their exclusion (Jordaan \& Heyde, 1979). Since that time, later studies generated research on the differences of career development on gender.

Herr and Enderlein (1976) looked at career maturity in male and female students from grades 9 th to 12 th. Over 1,500 students were given the CMI. The study indicated that the females demonstrated greater career maturity in ninth grade as compared to their male peers and this difference widened further by 12 th grade. The authors attributed this to a rapid maturation rate in girls as compared to boys.

The Attitude Scale of the Career Maturity Inventory (CMI-ATT) was given to 259 10th grade students; 54 black females, 80 white females, 38 black males, and 87 white males (McNair \& Brown, 1983). McNair and Brown looked into factors related to career maturity, occupational aspirations, and occupational expectations in minorities and females. They found that females scored higher than males across all three measures. Neely (1980) looked at career maturity in boys and girls in ninth grade and found that the girls scored higher means across all measures on the CMI. 
These studies seem to demonstrate that gender is an important factor when addressing career maturity in adolescents, and that females develop career maturity faster than males. Although there is different speculation to why this may be so, it is an important factor to be taken into account when looking at adolescents' career maturity.

\section{Mental Ability}

Several studies have investigated the relationship between career maturity and mental ability. Lawrence and Brown (1976) administered the CMI and the OtisLennon Mental Ability Test to examine the relationship between mental ability and career maturity. They found that career maturity is highly correlated with level of intelligence. In a similar study, Watson and Van Aarde (1986) utilized the CMI and a standardized group intelligence test to examine this same relationship in 600 South African black male and female 8th to 12th grade students. They too found a high correlation between mental ability and career maturity.

Westbrook, Sanford, O’Neal, Horne, Fleenor, and Garren (1985) investigated mental ability and career maturity in over 200 students in 11th grade, and found no significant correlation between these factors. The authors used grade point average (GPA) as a measure of constructs of scholastic aptitude and scholastic achievement, which they felt was an indication of mental ability. In contrast, a more recent study by Letcher-Glembo (1989) looked at the relationship of mental ability and career maturity in 40 adolescents with clefts as compared to 40 adolescents 
without clefts. Mental ability was found to be the strongest factor in the prediction of career maturity across the cleft and noncleft groups.

\section{Self-Concept}

Super's (1953) original theory of career maturity introduced self-concept as one of the major contributors to the theory. This variable has been the focal point of numerous studies. Lawrence and Brown (1976) studied this relationship using the CMI and the Tennessee Self Concept Scale (TSCS) (Fitts, 1965; 1991) administered to 266 twelfth graders. They found that self-concept had an impact on the prediction of career maturity level depending on race and sex of the subjects, with self-concept most largely serving as a significant predictor of career maturity level in males who were white. Mental ability proved to be a better predictor for females of any race as well as for males who were black in this study.

The Vocational Development Inventory Attitude Scale (VDI-Att) was given to 500 females and 500 males in an urban area of western New York (Pound, 1978). Pound explored the relationship of self-concept, race, and gender to career maturity. The results supported the conclusions of Lawrence and Brown's study (1976), that self-concept has a different impact depending on race and sex. However, Pound (1978) found that self-concept was a better predictor of career maturity level in black males than in black females and Caucasian individuals regardless of gender.

Jones, Hansen, and Putnam (1976) studied the relationship of self-concept and vocational maturity in 846 male and female students. The measurement tools 
given were the Vocational Development Inventory (Crites, 1978) and the TSCS. They found vocational maturity and self-concept to be significantly related for males, but not for females. McNair and Brown (1983) duplicated these results using CMI and the TSCS to test 259 black and white male and female subjects.

Holland's (1981) study of self-concept and career development in 300 grade school students indicated a low correlation between self-concept and vocational development. Socioeconomic status, in this study, was found to be the greatest predictor of career maturity as compared to the factors of self-concept, race, sex, place of residence, and age.

Findings across studies suggest that a relationship between self-concept and vocational maturity exists, although the extent of the relationship varies. Most studies suggest the extent varies with race and sex (Jones et al., 1976; Lawrence \& Brown, 1976; McNair \& Brown, 1983; Pound, 1978). The specific reasons of why and how self-concept impacts level of career maturity remains to be studied.

\section{Special Populations}

Studies of career development in populations that deviate from the norm have been limited. Those that have been conducted have revealed that tests of career maturity are useful in assessing the career development of special populations such as, emotionally maladjusted youth, academically talented youth, and delinquent youth (Karayani, 1981; Mori, 1982; Pavlak \& Krammer, 1985). Letcher-Glembo (1989) studied a group of adolescents, 40 cleft and 40 noncleft, in terms of their 
career development. She found, in order, the greatest predictors of career maturity level to be: mental ability, self-concept, educational aspirations, and acceptability of facial appearance as judged by others. This finding was consistent across the adolescents with clefts and without clefts involved in her study.

\section{Summary of the Factors That Affect Career Maturity}

Super introduced a theory of career development in 1953 and suggested that variables, such as mental ability and self-concept, could influence career development. Research has shown that a relationship exists between career maturity and age/grade (Herr \& Enderlein, 1976; Noeth \& Prediger, 1978; Super \& Thompson, 1979), gender (Herr \& Enderlein, 1976; Jordaan \& Heyde, 1979; McNair \& Brown, 1983; Neely, 1980), socioeconomic status (Holland, 1981), mental ability (Lawrence \& Brown, 1976; Watson \& Van Aarde, 1986), and selfconcept (Jones et al., 1976; Lawrence \& Brown, 1976; Pound, 1978). Special populations such as, emotionally maladjusted youth, academically talented youth, delinquent youth, and adolescents with cleft lip and palate have also demonstrated similar relationships of factors associated with career maturity (Karayani, 1981; Letcher-Glembo, 1989; Mori, 1982; Pavlak \& Krammer, 1985). The results of combined research suggest that career maturity increases systematically with age and that females progress at a faster rate than males. Findings regarding the impact of socioeconomic status and mental ability are inconclusive at this time, but it appears that these factors may be influential in some situations. Most studies indicate a 
positive correlation between mental ability and career maturity. Research suggests that the extent of the relationship between self-concept and career maturity varies with race and gender.

Review of the research demonstrates that career maturity is complex and dependent on many variables. It is probable that speech characteristics and facial appearance, particularly if strikingly deviant, may further contribute to variable levels of career maturity.

\section{Factors That Affect the Psychosocial Functioning of Adolescents With Clefts}

Cleft lip and palate is a frequent congenital anomaly that occurs in approximately 1 in 600 births (Moller, 1993). Typically, early intervention is provided to address feeding, surgical, and other basic health needs, and as a result, individuals with isolated clefting have no other major intellectual or physical problems that persist throughout their lives with the exception of facial and speech stigmata. As summarized by Letcher-Glembo (1989), "despite early and long-term care, frequent sequels of clefting include facial deformities, such as lip scarring, asymmetrical nares, and missing and/or maligned teeth, and speech deviations, such as articulation errors and hypernasality" (p. 9). Social adjustment and acceptability of facial appearance and speech are some of the main concerns of the interdisciplinary team who treats the adolescent individual born with a cleft. 
Effects of Facial Appearance on Behavior

Tobiasen (1987) stated that "the emphasis on social acceptability is based on the assumption that facial appearance is central to the development of normal peer relationships, healthy personal adjustment, and success in school and in career" (p. 323). She noted that physical attractiveness affects three components of the interpersonal attraction process:

First, people hold different expectations for the behavior of individuals with differing levels of attractiveness. Second, these expectations may lead to the differential treatment of attractive and unattractive children by adults and peers. Third, differential treatment may lead to differences in how attractive and unattractive children behave. (Tobiasen, 1984, p. 132)

Several studies have looked at individuals with clefts and found that people hold different expectations for individuals with varying levels of attractiveness. Clifford and Walster (1973) had approximately 500 fifth-grade teachers rate the popularity, intelligence level, and likelihood of having a successful career of children based on report cards that included an attached photograph of a child. The investigators utilized the same report cards but different photographs across the teacher raters. The teachers rated the students who were less attractive as "less popular," "less intelligent," and "less likely to have successful academic careers," supporting the concept that individuals have different expectations for individuals with differing levels of attractiveness.

Similarly, Schneiderman and Harding (1984) found that the presence of scarring from a repaired cleft lip, when judged by peers, resulted in a more negative 
evaluation of a child. Schneiderman and Harding had a group of 78 elementary students rate slides of children (some with bilateral cleft lip, some with unilateral cleft lip, and others demonstrated normal facial features) on 15 independent semantic differential variables. The bilateral cleft lip group was rated more negatively than the unilateral cleft lip group, and both groups with clefts were rated more negatively than the nonclefted children. The authors concluded that the resuits of this study agreed with previous research: children who are more physically attractive (normal facial appearance) are perceived as being more socially adjusted and well liked than those who are unattractive (cleft lip scarring).

Research has shown that adults display differential behaviors toward attractive and unattractive adults without facial disfigurements. This research has suggested that attractiveness affects helping behavior (Benson, Karabenick, \& Lerner, 1976), disciplinary action (Adams \& Cohen, 1974), response towards infants (Hildebrandt \& Fitzgerald, 1978), and employment opportunities (Adams, 1978). Results from a study by Tobiasen (1983), which looked at conduct problems of children with clefts compared to children without clefts, indicate that parents may display differential treatment depending on the child's physical condition and attractiveness.

Several studies have investigated the relationship between behavioral differences and facial appearance. Although many early studies attempted to reveal a cleft palate personality or psychopathology (Richman \& Eliason, 1986), more recent 
studies have focused on adjustment differences within the cleft population. A study by Schneiderman and Auer (1984) looked at parents' and teachers' ratings of children's emotional and social aspects. These children's behavior was characterized as shy and withdrawn by parents and teachers.

Kapp (1979) looked at children with clefts and children without clefts and compared differences in self-concept and related factors of behavior, intellectual and school status, physical attributes and appearances, popularity, anxiety, and happiness, and satisfaction. The P-H Children's Self Concept Scale was administered in which the children responded to 80 statements designed to look at the six areas of concern. Although no significant differences were found between the control and experimental groups on the global self-concept scores, significant differences were found on three cluster scores: anxiety, intellectual and school status, happiness and satisfaction. Furthermore when items related only to physical appearance were further isolated, a significant main effect by group was found on physical appearance score with the adolescents with clefts showing greater dissatisfaction with personal appearance.

Harper and Richman (1978) used the Minnesota Multiphasic Personality Inventory (MMPI) to study 46 adolescents with orthopedic disabilities and 52 adolescents with cleft lip/palate. They found greater behavioral inhibition in both groups compared with nondisfigured controls. Adolescents with cleft lip and palate 
displayed greater self-concern and greater self-doubt regarding interpersonal interaction than did those with orthopedic disabilities.

Broder et al. (1994) investigated self-ratings of satisfaction with appearance and accomplishment of psychological adjustment in 431 subjects with clefts. A standardized interview was used to collect data. The researchers found greater dissatisfaction with appearance in subjects who had visible defects (cleft lip and/or palate) than those with invisible defects (cleft palate only). The results also showed that a significantly higher percentage of subjects with clefts reported having more friends than other children. This study relied on the subjects self-report and the authors interpreted that this high rate of popularity reported could reflect denial or a higher need for acceptance for the cleft individuals, and speculated that perhaps the self-report data from these subjects tended to be exaggerated.

In a related study, Richman, Holmes, and Eliason (1985) looked at two groups of adolescents with clefts identified as well adjusted or poorly adjusted based on their parents' ratings of behavior. The two groups were compared on their selfratings of facial appearance and behavior. Their results indicated that the group that is well adjusted have realistic perceptions of facial appearance and behavior, while the poorly adjusted group have unrealistic perceptions of facial appearance and perceive their behavior as more socially acceptable than their parents or teachers. This suggests that it may not be the severity of facial appearance that leads to 
differences in behavior, but rather the discrepancy between the individual's selfperception and observer's perception of facial appearance.

A study by Letcher-Glembo (1989) that focused on career maturity of adolescents with clefts included self and objective ratings of facial appearance. The subjects who scored lower in career development appeared to be those in which there was a mismatch between self-perception of facial appearance and objective perception of facial appearance.

Other mild behavioral differences have been found to be related to appearance in adults with clefts. As summarized by Letcher-Glembo (1989), adults with clefts feel less secure in their employment and are out of work more frequently and for longer periods of time compared to the noncleft population. These findings can be interpreted as supporting Tobiasen's (1984) contention that facial appearance can affect expectations of others, and in turn lead to behavioral differences. Investigators have suggested that it may not be the severity of facial differences, but the unrealistic way with which individuals perceive their appearance (LetcherGlembo, 1989; Richman \& Eliason, 1986; Richman et al., 1985).

\section{Effects of Speech Characteristics on Behavior}

Research studies have found that the social acceptability of speech characteristics is related to peer acceptance, negative personality traits, occupational status, and the impact of speech characteristics on perceived notions of attractiveness (Addington, 1968; Blood \& Hyman, 1977; Glass, 1978; Penner, Belanger, \& Starr 
1978). Research has looked at the impact of speech characteristics on speakers and reaction of those with whom they are interacting. A study by Mowrer, Wahl, and Doolan (1978) examined the social consequences of adult listeners' first impression of lisping. Five adults were randomly selected to read a passage, 3 in their normal speaking manner and 2 were taught to lisp. The 5 speakers were rated by adult listeners with regard to speaking ability, intelligence, education, masculinity, and friendship. Results indicated that the adult speakers with a lisp were rated lower in all five categories then those who did not lisp. In a related study, Penner et al. (1978) investigated listeners' judgments of the importance of speech for success in three occupations with different levels of social status. They found that the quality of speech was judged to be important in the following occupations: lawyer, teacher, and sales clerk. The results indicated that the listeners associated different speech characteristics with different occupations, associating good speech with high social status and poor speech with low social status. Other studies reviewed by LetcherGlembo (1989) have indicated that negative personality traits and social status, a listeners' perception of physical attractiveness, and listeners recall of information have all been affected and associated with the presence of nasality in speech.

One study by Richman (1983) looked at the relationship among self-perceived social adjustment, objective personality assessment, concerns regarding facial disfigurement, and defective speech in 30 adolescents with cleft lip and palate. Using the MMPI, the subjects responded to questions regarding self-perceptions of facial 
appearance and speech. A two-way analysis of variance (ANOVA) was used to evaluate the possible effects of self-expressed concern regarding speech versus facial disfigurement on social adjustment (Social Introversion scale). The results indicated a significant main effect for facial concerns while no significant main effects for speech concerns were observed. This significant main effect indicated that cleft adolescents with a moderate-to-great degree of facial concern have significantly higher scores on the Social Introversion scale than clefts with only a slight-to-no facial concern. Further comparisons indicated that whenever there was high facial concern, Social Introversion scores were significantly higher, regardless of the degree of speech concern. However, the author did note that there were as many adolescents with clefts who expressed moderate-to-great concern with speech as they did with facial appearance. Richman interpreted this finding as indicating that subjects concerned with speech have learned to adjust more adequately because of a realistic acceptance of speech patterns. Those who have continued concerns regarding facial appearance, continue to expect or hope for facial surgery, creating greater dissatisfaction with self.

Letcher-Glembo (1989) looked at career maturity in adolescents with clefts, and the factors that might affect that maturity, including self and objective ratings of speech acceptability. The results showed that adolescents with clefts received lower rating of speech acceptability when judged by a panel of listeners. However, the cleft subjects' ratings of their own speech was not lower than the control subjects' 
ratings of their own speech. The author interpreted this finding in two ways: (a) either the subjects with clefts, having many years of speech intervention, accept their speech in relation to what they expect to accomplish with their speech, or (b) the subjects with clefts are unrealistic in their own perceptions of their speech.

There is considerably less research in the area of speech acceptability and characteristics and its impact, than the impact of facial appearance. From the research available, it is apparent that some speech deviations can possibly affect career development (Penner et al., 1978), judgments of intelligence (Mowrer et al., 1978), and degree of self-concern (Richman, 1983). The research currently available on the relationship between career maturity and speech characteristics is limited and needs further exploration (Letcher-Glembo, 1989).

Summary: Factors That Affect the Psychosocial Functioning of Adolescents with Clefts

Mild facial disfigurement and speech deviations often persist in individuals with clefts throughout the scope of their lives. There are signs of increased inhibition and social withdrawal in the cleft population (Harper \& Richman, 1978; Kapp, 1979), that may effect social interactions and future career choices. Although it is important to the clinical management of persons with clefts, few studies have looked at the impact of speech and facial deviations on social status, educational aspirations, or occupational attainment. 


\section{Effects of Orofacial Clefts on Career Development}

Limited research has focused on the effects of orofacial clefts on career development. Letcher-Glembo (1989) investigated the career maturity of 40 adolescents with clefts and 40 noncleft peers matched for gender and age. Subjects were given the CDI, the TSCS, and the Shipley Institute of Living Scale (SILS) to determine career maturity, self-concept, and mental ability. Biographical data, selfratings of facial appearance and speech, and photographs and tape recordings of speech samples were also obtained from each subject.

The results indicated that mental ability, self-concept, the panel's judgments of facial appearance, and subjects' educational aspirations were factors that were predictive of career maturity. The finding that mental ability and self-concept were predictive factors was anticipated and supports findings of early research on career maturity. However, the panel's ratings of facial appearance as a significant predictor of career maturity level was not expected; earlier studies had not addressed this issue. This finding, however, appears to be related to earlier studies in which adolescents with clefts who have personality adjustment problems tend to rate their appearance as more socially acceptable than independent raters (Harper \& Richman, 1978; Richman et al., 1985). This study did not find that the self-ratings of facial appearance contributed to the prediction of career maturity.

Letcher-Glembo's (1989) earlier research was limited, however, in that all participants with clefts did not necessarily demonstrate speech and facial differences. 
The cleft group was composed of subjects with clefts of the lip, palate, or lip and palate, so not all demonstrated cleft lip and palate. This factor may have masked the importance of the impact of facial differences. In order to fully understand the impact of orofacial clefting on career maturity, further research needs to be done to account for this additional factor.

\section{Summary}

Persons born with cleft lip and palate often have speech and facial differences that may last throughout ones life. Previous research has shown that individuals with clefts show increased inhibition, social withdrawal, and low self-concept (Harper \& Richman, 1978; Kapp, 1979; Richman, 1976; Richman \& Eliason, 1986). These findings have suggested that speech and facial deviations may lead to these behavioral differences. Most recent research has indicated that individuals' unrealistic perceptions of their speech and facial appearance may actually produce these behavioral differences (Richman \& Eliason, 1986; Letcher-Glembo, 1989; Broder et al., 1994).

Studies of noncleft adolescents indicate that career maturity scores are predictive of later success and satisfaction in career choices. Career maturity scores are related to age, gender, self-concept, and mental ability. Socioeconomic status and independent and self-ratings of speech and facial appearance may also be related. 
Limited research has looked at the effects of facial appearance and speech deviations, such as those associated with clefting, on career maturity. Currently, professionals who work in the habilitative domain of individuals with clefts are left to their own clinical instincts and experiences because of the lack of research with this population. In order to understand the psychological and sociological variables that aid in career development of adolescents with clefts, further research in this area needs to be completed. 


\section{CHAPTER III}

\section{METHODS}

This study was designed to compare the career maturity of two age groups of male adolescents with cleft lip and palate (14- and 17-year-olds) and two age groups of female adolescents with cleft lip and palate (14- and 17-year-olds) to determine the extent to which age, gender, self-concept, mental ability, facial appearance, and speech affect their career maturity. This study is a component of a larger study underway focusing on the career development of adolescents (14 through 17 years) and young adults (18 through 21 years), cleft and noncleft, being conducted at Portland State University by Lisa Letcher-Glembo, speech-language pathologist and assistant professor. The current study solely targeted subjects with cleft lip and palate in two age groups. Specifically this study of adolescents with cleft lip and palate focuses on 14-year-old males, 14-year-old females, 17-year-old males, and 17-year-old females.

In order to complete the study, it was necessary to select subjects; to administer tests of career maturity, mental ability, and self-concept; to obtain selfratings of speech and facial appearance. The following summarizes subject selection and recruitment, test procedures, and rationale for choice of instruments used in this study. 
Subject Recruitment

\section{Proposed Subject Sample Pool}

While clefting occurs 1 in 600 live births, only about $50 \%$, or 1 in 300, of these individuals demonstrate cleft lip and palate. It is not uncommon for individuals with clefts to be followed by a team from birth until approximately 21 years of age. These factors considered, the following subject sample pool was developed to enable sufficient power for statistical analysis. The target sample pool for this study of adolescents with cleft lip and palate was as follows: five 14-year-old males, five 14year-old females, five 17-year-old males, and five 17-year-old females. Data were available from the earlier Letcher-Glembo (1989) study conducted in Minnesota for the following subjects with cleft lip and palate: one 14-year-old male, three 14-yearold females, four 17-year-old males, and four 17-year-old females. The remaining number of subjects needed to be recruited for the current study were: four 14-yearold males, two 14-year-old females, one 17-year-old males, and one 17-year-old female.

\section{Identification and Recruitment of Cleft Subjects}

Twelve subjects were recruited and tested in a previous study by LetcherGlembo (1989) through three interdisciplinary agencies providing comprehensive cleft habitation in the state of Minnesota: University of Minnesota's Cleft Palate Maxillofacial Clinic, Minnesota State Department of Health's Services for Children 
with Handicaps, and Logan Levin Cleft Palate Clinic. The study protocol used was identical to that employed in the current study'. The 12 subjects met this study's criteria for inclusion having cleft lip and palate, as well as being 14- or 17-years of age when they participated in the study.

The remaining subjects with cleft lip and palate were recruited by LetcherGlembo and this researcher through three interdisciplinary agencies providing comprehensive cleft habitation within the state of Oregon: Oregon Health Science University's (OHSU) Child Development and Rehabilitation Center (CDRC) Craniofacial Disorders Team-Portland Branch, OHSU's CDRC Craniofacial Disorders Team-Eugene Branch, and Kaiser Permanente's Cleft Lip and Palate Team-Sunnyside Branch. Subjects who met age, gender, and cleft type criteria were identified through each agency's data base. All subjects who met the study criteria for inclusion were mailed a consent form with, when needed, a corresponding cover letter, approved by each respective agency's Use of Human Subjects in Research Committees, describing the study and requesting their participation (Appendixes A, B, and C). Subjects mailed back a response agreeing or declining to participate. Individuals who agreed to participate, had parental permission to do so, and met all criteria were contacted and scheduled until the predetermined number of males and females for each targeted age group was obtained or the subject data pool was exhausted. Subjects were not paid for their participation in this study.

${ }^{1}$ Use of human subject approval was obtained and is on record. 


\section{Response Rate}

Subject recruitment to fill proposed subject sample pool occurred February 1, 1997, through June 13, 1997. A total of 80 recruitment letters were sent out to all potential subjects served across the three Oregon Agencies providing comprehensive cleft palate team care, namely: OHSU's CDRC Craniofacial Disorders TeamPortland Branch, OHSU's CDRC Craniofacial Disorders Team-Eugene Branch, and the Sunnyside Branch of Kaiser Permanente Cleft Lip and Palate Team. The specific mailing and return rate distribution is as follows. Sixty-seven letters were mailed to potential subjects through OHSU's CDRC Craniofacial Disorders Team-Portland Branch. Nineteen out of the 67 , or approximately $29 \%$, were returned as a result of incorrect address. Addresses were verified with the respective agency as well as, when possible, telephone book listings. No additional mailings of the 19 initially returned were deliverable despite these attempts. One recruitment letter was returned by family because the subject had deceased. Seven responses were returned by potential subjects, six agreeing to participate and one declining to participate in the study. Eleven letters were mailed to potential subjects through OHSU's CDRC Craniofacial Disorders Team-Eugene Branch, with 1 out of the 11 subjects agreeing to participate. Two letters were mailed through Kaiser Permanente with no response from the subjects prior to closure of the study.

In terms of data collection, for the 80 potential subjects (based on age and cleft condition) in the state of Oregon, response rate data are summarized below. 
Twenty-four percent were returned due to wrong address, despite second mailing and then re-verification of address with the client's agency in which the client was served. Of the 61 recruitment letters believed to have been delivered to potential subjects, 7 individuals or $12 \%$ agreed to participate, 1 declined to participate, and 48 individuals (79\%) failed to respond to the request despite a second mailing. The investigators were not allowed to complete follow-up recruitment phone calls per human subject committees.

\section{Subject Selection}

\section{Cleft Palate Subject Criteria}

The following criteria were used in selection of the subjects with cleft lip and palate who participated:

1. Subjects were 14 or 17 years of age, as these two age groups provide a cross section sampling of the ages in which career maturity is considered to be predictive of eventual career success and satisfaction.

2. Subjects were enrolled in regular education classes. The applicability of available measure of career maturity with individuals with learning disabilities is unknown.

3. Approximately one-half of the sample was at each age level. Previous studies have indicated that age of subjects may affect career maturity level. 
4. Approximately one-half of the subjects were male and one-half were female. Previous studies have indicated that gender of subjects may affect their level of career maturity.

5. Subjects had written parental approval to participate in the study.

6. Subjects did not have neurological, physical, or severe medical problems with the exception of the orofacial cleft.

7. Subjects had cleft lip and palate (unilateral or bilateral).

8. The type of physical management used in repairs of the clefts of the lip or palate was not considered in subject selection.

\section{Einal Sample}

Using the established criteria and recruitment procedures, 19 subjects were recruited to participate in the study. Table 1 summarizes the final distribution of subjects for the cross sectional age groups.

\section{TABLE 1}

ADOLESCENTS: NUMBeR OF SUBJeCTS WITH OROFACIAL ClefTiNG IN EACH AGE AND GENDER GROUP

\begin{tabular}{|l|c|c|c|}
\hline & \multicolumn{2}{|c|}{ Age } & \\
\hline & 14 Years & 17 Years & Subtotals by Gender \\
\hline Male & 5 & 4 & 9 \\
\hline Female & 5 & 5 & 10 \\
\hline
\end{tabular}




\section{Measures and Procedures}

All subjects completed measures of career development, self-concept, mental ability, and self-ratings of speech and facial appearance. The Career Development Inventory School Form (CDI-S) was used to measure level of career maturity, the Shipley Institute of Living Scale (SILS) was used to estimate mental ability, and the Tennessee Self Concept Scale (TSCS) was used to assess overall self-concept. Sevenpoint Likert-type scales were utilized for self-ratings of speech and facial appearance acceptability.

The test measures, procedures, and method of data collection were identical to those followed in the Minnesota study with exception of test administrator and subject recruitment cover letter. Each subject recruited in Oregon was tested in a single data-gathering session that took place in the adolescent's own home. All tests were administered by this investigator. Subjects were seated in a quiet room free from noise and distractions. Parents were in the home, but not in the room during test administration. Descriptions of tests and instruments administered, as well as test protocols followed are listed below.

\section{Career Development Inventory}

The Career Development Inventory School Form (CDI-S) was used as the measure of career maturity. Copyright laws prohibit inclusion of a CDI-S protocol in the appendix of this document. Sample questions include: (a) How much thinking 
and planning have you done about taking classes which will help you decide what line of work to go into when you leave school or college? (b) Keeping in mind the type of job you think you might like to be in after you finish you schooling, how much knowledge to you have about what people really do on the job? This measurement consists of two parts. Part 1 (Career Orientation) consists of four scales that looks at conative and cognitive factors and combine to derive a Career Orientation Total (COT). The conative scales include questions about career planning and career exploration, and the cognitive scales include questions about decision-making and world-of-word information. Part 1 is comprised of 80 multiple choice questions and takes approximately 40 minutes to administer. Part 2 consists of 40 multiple-choice questions about knowledge of the test-takers preferred occupational group. Part 2 of the CDI was not administered because of time constraints. Responses to Part 2 do not contribute to the total career orientation score. The test cannot be hand-scored; subject responses are mailed to the publisher and computer scored. As summarized and cited by Letcher-Glembo (1989), the CDI has been subjected to extensive reliability and validity studies. The reliability coefficients for male and female adolescents, grades ninth through 12th, range from .82 to .87 . The nature of the measurements provided in the CDI, the extent to which its validity and reliability have been determined across age and diverse cultural groups, and the existence of normative data suggest that it was the best measurement tool available for the purposes of this study. 


\section{Shipley Institute of Living Scale}

The Shipley Institute of Living Scale (SILS) was administered as a screening measure to estimate mental ability. The scale consists of two subtests (a 40-item vocabulary test and a 20 -item test of abstract thinking) and measures the discrepancy between vocabulary and abstract concept formation. Copyright laws prohibit inclusion of test protocol in the appendix of this document. The Vocabulary Subtest instructs the test taker to "circle the word which means the same thing, or most nearly the same thing, as the word in capital letters." Examples of sample items (correct response italicized) are as follows: (a) REMEMBER (choices are: swim, recall, number, defy), (b) FORTIFY (choices are: submerge, strengthen, vent, deaden), and (c) QUERULOUS (choices are: maniacal, curious, devout, complaining). The Abstraction Subtest involves completion of the blanks. Sample items from this subtest include: (a) $12345 \ldots$ (correct answer is 6), (b) escape scape cape _ _ _ (correct answer is ape), and (c) lag leg pen pin big bog rob _ _ administered. The total administration time for the test is 20 minutes, 10 minutes for each subtest. Responses are hand scored to yield a Vocabulary Score, an Abstraction Score, and a Total Score. Numerous studies have demonstrated the validity of the SILS (Paulson \& Lin, 1970). Data on its internal consistency, test-retest reliability, standard error of measure, and validity are provided (Zachary, 1987). The reliability 
coefficient for male and female adolescents is .78. Data indicate that the SILS is a reasonably valid and reliable measurement instrument.

\section{Biographical Questionnaire and Occupational Status Scores}

A biographical questionnaire constructed by Letcher-Glembo (1989) was utilized to obtain occupational and educational information about subjects and their parents (Appendix D). This information was not used for the current study, but was taken as part of the protocol for the larger study by Letcher-Glembo.

\section{Tennessee Self Concept Scale}

The TSCS (1996) was given to assess self-concept. This measurement is selfadministered and consists of 82 self-descriptive statements that allow individuals to portray their own self-picture using the following five response categories: always false, mostly false, partly false and partly true, mostly true, and always true. Copyright laws prohibit inclusion of a CDI-S protocol in the appendix of this document. Sample statements include: (a) I am an attractive person, (b) I am a decent sort of person, and (c) I take a real interest in my family. The test results are hand scored to determine a total score based on the following six self-concept scales: physical, moral, personal, family, social, and academic/work. The form takes 10 to 20 minutes to administer and is not timed. The test-retest reliability coefficient for adolescents is $\mathbf{8 2}$. The scores provided in the TSCS, its demonstrated validity and reliability, and its proven usefulness as an instrument that distinguishes between 
different groups, particularly clinical and nonclinical ones (Walsh, 1984), suggested that the TSCS was the best measurement tool available for the purposes of this study.

\section{Self-Rating of Speech and Facial Acceptability}

A 7-point bipolar adjective scale constructed by Sinko and Hedrick (1982) was used to obtain self-perceptions of speech and facial appearance (Appendix E). The scale was anchored on either end by the verbal descriptions very unacceptable and very acceptable and had verbal descriptions for each interval point in between. As cited by Letcher-Glembo (1989), Likert-type rating scales of this type have been useful in obtaining ratings from naive and sophisticated observers who have varied in age, gender, race, and familiarity with the subject. Ratings of facial appearance and speech acceptability were made on separate response sheets. Responses for speech and facial ratings were later coded for data analysis as numbers were not placed on the response sheets used by the subjects.

\section{Photographs}

Full-face photographs were taken using a Pentax K1000 camera and Albinar ADG $52 \mathrm{~mm}$ lens. Photographs were limited to a head and neck portrait, taken 6 feet away using $60 x$ shutter speed. As demonstrated by Letcher-Glembo (1989), this procedure has been found to result in photographs of consistent quality. The 
photographs were not used for the current study, but were taken as part of the protocol for the larger study by Letcher-Glembo.

\section{Tape Recordings}

Tape recorded speech samples were made by having the subjects read aloud a standardized reading passage "Lazy Jack" (Appendix F). A dubbed sample of this recording was later used by a panel of listeners to rate speech acceptability. Recordings were made on a portable tape recorder using a condenser microphone placed 6 inches form the speaker's mouth. This procedure has been previously tested (Letcher-Glembo, 1989) and results in consistent quality of recordings. The speech samples were not used for the current study, but were taken as part of the protocol for the larger study by Letcher-Glembo.

\section{Order of Presentation}

Subjects were seen independently for a single data gathering session that ranged from 1 hour and 15 minutes, to 2 hours and 45 minutes, to complete. Data were collected in the following order: a full-face photograph, recorded speech sample, CDI, biographical questionnaire, SILS, self-rating of facial appearance, selfrating of speech acceptability and last, the TSCS. This order was chosen because it balanced difficult and easy tasks, tended to keep subjects from fatiguing, and limited influence of responses on subsequent tasks, as supported by an earlier study 
(Letcher-Glembo, 1989). After all subjects had been tested for the study, test responses were scored.

\section{Data Analysis}

Procedures used in the proposed study generated a score for the dependent variable of career maturity and a number of independent variables. To answer the first question posed in this study, "Do two age groups of male adolescents with cleft lip and palate (14- and 17-year-olds) differ from two age groups female adolescents with cleft lip and palate (14- and 17-year-olds) in level of career maturity?" descriptive statistics were employed in terms of range, means, and standard deviations. Least Squares Means were computed to take into account interaction between variables. A two-way ANOVA was completed to take into account the interactional effect of age on career maturity. A $t$-test analysis was not completed on the Career Orientation Total (COT) based on the recommendation of two statisticians, one from Portland State University, the other from Oregon State University, who felt that ANOVA technique was preferable due to the anticipated combined effects of gender and age. An alpha level of .05 was chosen.

The second question posed in this proposed study was, "Do two age groups of male adolescents with cleft lip and palate (14- and 17-year-olds) differ from two age groups of females with cleft lip and palate (14- and 17-year-olds) in factors thought to be related to career maturity?" Such factors include: mental ability, self- 
concept, self-rating of speech, and self-rating of facial appearance. Information from the SILS, TSCS, and self-ratings of speech and facial appearance, was used to respond to this question. Analyses were completed to look at isolated and combined factor effects. To account for the small sample size, factors thought to be related to level of career maturity were first analyzed with the total sample of male and female adolescents combined to detect which variables demonstrated a significant relationship to level of career maturity. Significant factors were than analyzed for age and gender effects. Pearson $r$ Product Correlation Coefficients were used to examine the correlation between the CDI, SILS, and TSCS. A positive number at or approaching the value one indicates a positive relationship between factors, while a negative number at or approaching the value negative one indicates a negative relationship between factors. Numbers close to zero, indicate a low or weak correlation between factors. A two-way ANOVA was used to investigate the combined effects of age and gender on level of career maturity. A two-way ANOVA and four-factor ANOVA were used to compare each of the three measures to selfratings of speech and facial appearance. The alpha level was set at .05 . Follow-up one-way ANOVAs were completed as needed. 


\title{
CHAPTER IV
}

\section{RESULTS AND DISCUSSION}

\author{
Results
}

The purposes of this study were to determine if a difference in level of career maturity exists between two age groups of male and female adolescents with clefts, and to determine the effects of self-concept, mental ability, facial appearance, and speech acceptability, in addition to age and gender on career maturity. Nineteen adolescents with cleft lip and palate were tested on measures of career maturity, selfconcept, and mental ability, and completed self-ratings of facial appearance and speech. Study limitations will be discussed followed by presentation of this studies findings.

\section{Study Limitations}

There are several limitations within the design of this study that could affect the results. First, the sample size was small. It would be preferable to have a greater number of subjects. However, this would require collaboration across agencies serving individuals with clefts not only within but also outside of the state of Oregon which was beyond the scope of this project. More subjects would determine with greater accuracy if a difference between gender and level of career maturity exists in 
this special needs population. Furthermore, the unmatched number of subjects in the present study between males and females prevented more powerful statistics from being employed. Given the results of past research, it would have been useful if larger or equally matched gender groups could have been recruited. A potential related limiting factor is the number of subjects who failed to respond to the request to participate. The groups should have been able to be matched based on the potential number of subjects who met the study criterion within the state of Oregon. It is noted that the principle investigator was not serving these potential subjects directly through a current affiliation with a cleft lip and palate team. While a cover letter from each respective agency served as the recruitment letter, the lack of "connectedness" or association with Portland State University who was "conducting the study" may have contributed to the decreased motivation to respond. Further research could include a control group, matched not only for age and gender, but also matched in terms of other factors such as, self-concept. This observation was noted by a recent National Institute of Health grant reviewer who had the opportunity to critique the study protocol.

Other limitations include the possibility of a biased sample of adolescents with cleft lip and palate. The adolescents who responded to the request to participate may be those individuals (or their families) who were concerned about their career development. It is possible that adolescents still followed by a comprehensive cleft lip and palate team are those individuals having persisting difficulty with speech, 
facial appearance, and adjustment factors. It could be argued, perhaps that adolescents followed by comprehensive cleft lip and palate teams are receiving optimal care.

Adding a measure of observers' rating would account for previous research that indicates a match or mismatch between self-rating and observer ratings are important determiners in one's behavior in terms of adjustment level. Discrepancies between an individual's self-perception and observer's perception of facial appearance and speech may lead to behavioral differences (Letcher-Glembo, 1989; Richman, Holmes, \& Eliason, 1985).

Subjects were not paid for their participation in the study. Study enrollment may have been higher if there had been a monetary reward for participating. Subjects who have higher levels of positive self-concept and higher levels of mental ability may have been more likely to participate in the study as they may have been able to recognize potential intrinsic rewards.

\section{Career Maturity Level Findings}

The CDI Career Orientation Total (COT) standard scores are listed for the male and female subjects in this study in Tables 2 and 3. Results are reported as standard scale scores, not raw scores because the subtests differ in types of items and scoring procedures. According to the CDI test protocol norms, the standard score used has a mean of 100 and standard deviation of 20 . Results of standard scores for male adolescents with cleft lip and palate in this study are as follows: 7 males 
TABLE 2

INDIVIDUAL MALE SUbJect SCORES ACROSS STUdy MEASURES

\begin{tabular}{|c|c|c|c|c|c|}
\hline $\begin{array}{c}\text { Subjects Listed According to } \\
\text { Age and Testing }\end{array}$ & $\begin{array}{c}\text { CDI COT } \\
\text { Standard } \\
\text { Scores }^{2}\end{array}$ & $\begin{array}{c}\text { SILS } \\
t \text {-scores }\end{array}$ & $\begin{array}{c}\text { TSCS }^{\text {c }} \\
t \text {-Scores }\end{array}$ & $\begin{array}{c}\text { Self-Rating } \\
\text { Facial } \\
\text { Appearance }\end{array}$ & $\begin{array}{c}\text { Self- } \\
\text { Rating }^{\text {Sar }} \\
\text { Speech }\end{array}$ \\
\hline 14 years, 05 months & 111 & 47 & 63 & 7 & 7 \\
\hline 14 years, 06 months & 101 & 53 & 50 & 6 & 6 \\
\hline 14 years, 06 months & 102 & 59 & 64 & 7 & 6 \\
\hline 14 years, 07 months & 92 & 48 & 52 & 6 & 6 \\
\hline 14 years, 10 months & 79 & 41 & 29 & 4 & 4 \\
\hline 17 years, 00 months & 83 & 55 & 37 & 6 & 6 \\
\hline 17 years, 03 months & 127 & 61 & 43 & 7 & 5 \\
\hline 17 years, 05 months & 89 & 53 & 40 & 7 & 7 \\
\hline 17 years, 08 months & 105 & 55 & 46 & 4 & 4 \\
\hline
\end{tabular}

Note: $\quad{ }^{a}$ Career orientation Total Standard Scores are normed for a $\bar{x}$ of 100 with $S D$ of 20.

bShipley Institute of Living Scores (SILS) are reported in $t$-scores with a normed $\bar{x}$ of 47.7 and $S D$ of 11.3.

${ }^{\mathrm{c}}$ Tennessee Self Concept Scores (TSCS) are reported in $t$-scores with a normed $\bar{x}$ of 47.7 and $S D$ of 9.7 .

${ }^{\mathrm{d}}$ Self-ratings of Speech Acceptability are reported in numerical form based on the following scale: 1 = very unacceptable, 2 = somewhat unacceptable, $3=$ a little unacceptable, $4=$ equally acceptable and unacceptable, $5=$ a little acceptable, 6 = somewhat acceptable, 7 $=$ very acceptable.

'Self-ratings of Facial Appearance Acceptability are reported in numerical form on the same Likert-type scale as listed above for self-rating of speech acceptability.

displayed levels of career maturity within 1 standard deviation of the mean. Of these

7 males with CDI scores within 1 standard deviation of the mean, 4 male subjects

scored above the mean of 100 and 3 male subjects scored below the mean of 100 .

One male subject displayed a level of career maturity more than 1 standard deviation above the mean, and 1 male subject displayed a level of career maturity more than 1 
standard deviation below the mean. Results of standard scores for female adolescents with cleft lip and palate in this study are as follows: 7 female subjects displayed levels of career maturity within 1 standard deviation of the mean ( 5 scored above and 2 scored below the mean of 100), 2 female subjects displayed levels of career maturity more than 1 standard deviation above the mean, and 1 female displayed a level of career maturity greater than 2 standard deviations above the mean.

\section{TABLE 3}

\section{INDIVIDUAL FEMALE SUBJECT SCORES ACROSS STUdy MEASURES}

\begin{tabular}{|c|c|c|c|c|c|}
\hline $\begin{array}{c}\text { Subjects Listed According to } \\
\text { Age and Testing }\end{array}$ & $\begin{array}{c}\text { CDI COT } \\
\text { Standard } \\
\text { Scores }^{\mathbf{a}}\end{array}$ & $\underset{t \text {-scores }}{\text { SILS }^{b}}$ & $\begin{array}{l}\text { TSCS }^{\mathrm{c}} \\
t \text {-scores }\end{array}$ & $\begin{array}{l}\text { Self-Rating }^{\mathrm{d}} \\
\text { Facial } \\
\text { Appearance }\end{array}$ & $\begin{array}{c}\text { Self- } \\
\text { Ratinge } \\
\text { Speech }\end{array}$ \\
\hline 14 years, 01 months & 95 & 45 & 61 & 7 & 7 \\
\hline 14 years, 01 months & 81 & 31 & 35 & 1 & 2 \\
\hline 14 years, 05 months & 106 & 42 & 55 & 6 & 7 \\
\hline 14 years, 07 months & 115 & 60 & 69 & 5 & 6 \\
\hline 14 years, 08 months & 104 & 51 & 53 & 7 & 2 \\
\hline 17 years, 02 months & 122 & 62 & 34 & 6 & 7 \\
\hline 17 years, 03 months & 112 & 44 & 54 & 7 & 7 \\
\hline 17 years, 05 months & 111 & 50 & 44 & 6 & 5 \\
\hline 17 years, 10 months & 144 & 57 & 54 & 5 & 4 \\
\hline 17 years, 11 months & 134 & 54 & 51 & 7 & 6 \\
\hline
\end{tabular}

Note: $\quad{ }^{2}$ Career orientation Total Standard Scores are normed for a $\bar{x}$ of 100 with $S D$ of 20.

${ }^{\text {b}}$ SILS are reported in $t$-scores with a normed $\bar{x}$ of 47.7 and $S D$ of 11.3.

'TSCS are reported in $t$-scores with a normed $\bar{x}$ of 47.7 and SD of 9.7.

$d$ and eSelf-ratings of Speech Acceptability and of Facial Appearance Acceptability are reported in numerical form based on the following scale: 1 = very unacceptable, 2 = somewhat unacceptable, 3 = a little unacceptable, $4=$ equally acceptable and unacceptable, $5=a$ little acceptable, 6 = somewhat acceptable, 7 = very acceptable. 


\section{Mental Ability Findings}

The measure of mental ability, SILS scores, are listed for the male and female subjects in Tables 2 and 3, respectively. Results are reported as $t$-scores. The $t$-score used has a mean of 54.7 and standard deviation of 11.3 , according to norms provided in the SILS test manual. Results of $t$-scores for male adolescents with cleft lip and palate in this study are as follows: 8 males displayed levels of mental ability within 1 standard deviation of the mean. Of these 8 males with mental ability scores within 1 standard deviation of the mean, 4 male subjects scored above the mean of 54.7 and 4 male subjects scored below the mean of 54.7. One male subject displayed a level of mental ability more than 1 standard deviation below the mean. The range of $t$-scores for the male adolescents was 41 to 61 , with a mean of 52.8. Results of $t$ scores for female adolescents with cleft lip and palate in this study are as follows: 8 female subjects displayed levels of mental ability within 1 standard deviation of the mean ( 3 scored above the mean of 54.7 and 5 scored below the mean of 54.7), and 2 females displayed a level of mental ability greater than 2 standard deviations below the mean. The range of $t$-scores for the female adolescents was 31 to 62 , with a mean of 49.2. The $t$-score results for males and females are visually displayed in Figure 1. 


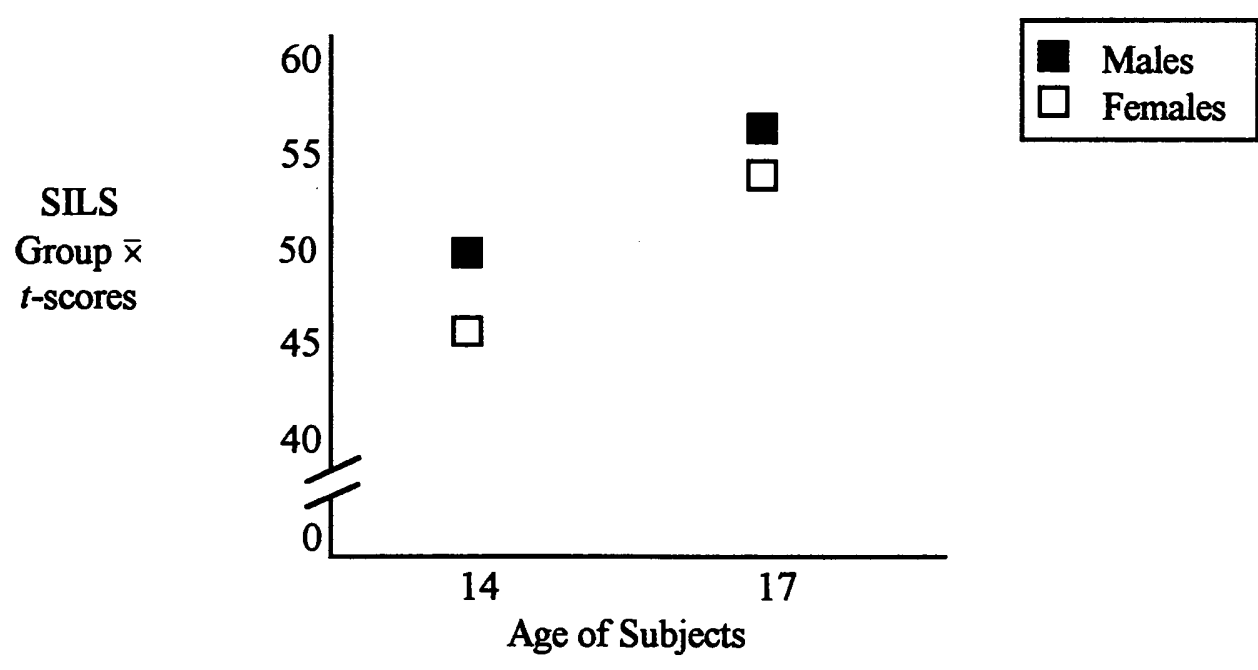

FIGURE 1

SHIPLEY INSTITUTE OF LIVING MEAN $T$-SCORES FOR MALE AND FEMALE GROUPS ACCORDING TO AGE

\section{Self-Concept Findings}

The measure of overall self-concept, TSCS positive scores, are listed in Table 2 for male subjects and Table 3 for females subjects. The results of the TSCS are reported as $t$-scores. According to TSCS test manual, the normed $t$-score has a mean of 47.7 and standard deviation of 9.7. Results of $t$-scores for male adolescents with cleft lip and palate in this study are as follows: 5 males displayed levels of selfconcept within 1 standard deviation of the mean. Of these 5 males with positive selfconcept scores within 1 standard deviation of the mean, 3 male subjects scored above the mean of 47.7 and 2 male subjects scored below the mean of 47.7 . Two male 
subjects displayed a level of self-concept more than 1 standard deviation above the mean, and 2 male subjects displayed a level of self-concept more than 1 standard deviation below the mean. The range of $t$-scores for the male adolescents was 29 to 64 , with a mean of 46.55 . Results of $t$-scores for female adolescents with cleft lip and palate in this study are as follows: 6 female subjects displayed levels of selfconcept within 1 standard deviation of the mean (5 scored above the mean of 47.7 and 1 scored below the mean of 47.7$), 2$ female subjects displayed levels of selfconcept more than 1 standard deviation below the mean, and 2 females displayed a level of career maturity more than 1 standard deviation above the mean. The range of $t$-scores for the female adolescents was 34 to 69 , with a mean of 51.3. The $t$-score results for males and females are visually displayed in Figure 2.

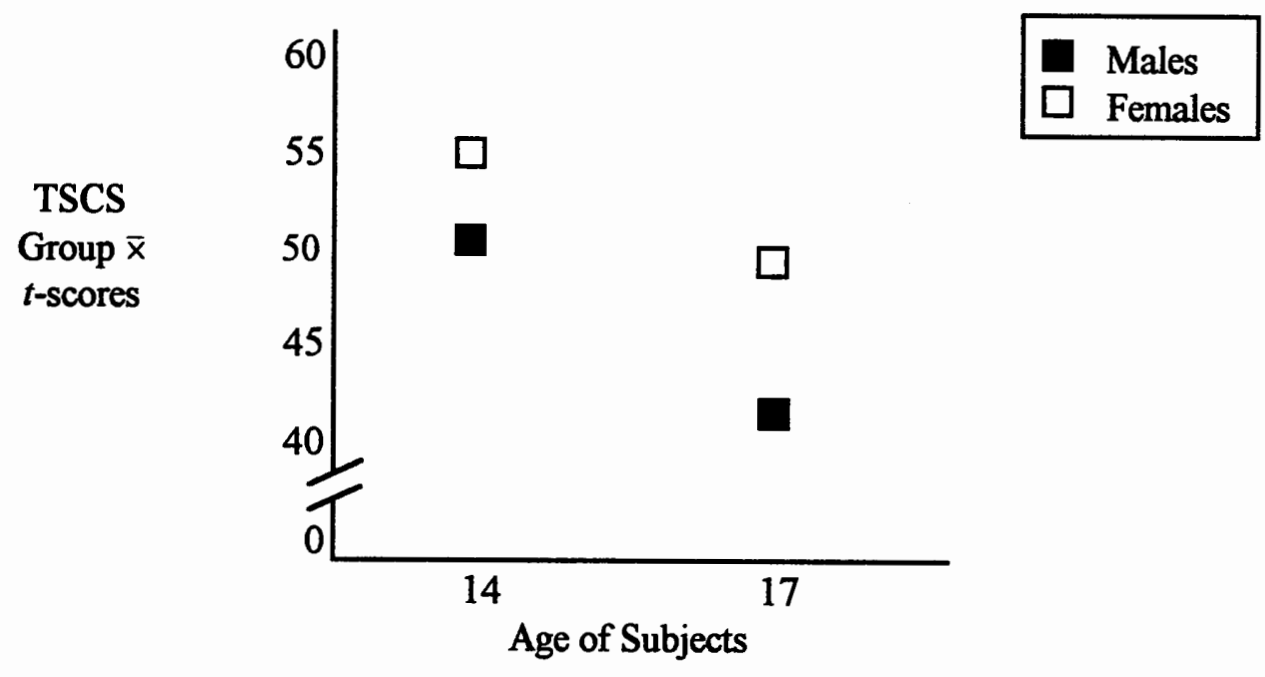

FIGURE 2

TENNESSEe Self-ConcePt SCALE MEAN $T$-SCORES For MALE AND FeMAlE GROUPS ACCORDING TO AGE 


\section{Self-Ratings of Speech and Facial Appearance Findings}

Self-ratings of speech and facial appearance were given values that ranged from 1 (very unacceptable) to 7 (very acceptable), the most positive rating being 7 and the most negative rating being 1 . Male and female individual self-ratings are listed in Tables 2 and 3, respectively. The results of self-ratings of speech for the subjects in this study are as follows: the range of scores for the male adolescents with cleft lip and palate was 4 (equally acceptable and unacceptable) to 7 (very acceptable) with a mean of 6 (somewhat acceptable), and for the female adolescents was 1 (very unacceptable) to 7 (very acceptable) with a mean of 5.7, suggesting females subject felt on average their speech was somewhat acceptable. The results of the self-ratings of facial appearance for the subjects in this study are as follows: the range of scores for the male adolescents was 4 (equally acceptable and unacceptable) to 7 (very acceptable) with a mean of 5.7, which suggest male subjects, on average, felt their facial appearance was somewhat acceptable. The range of scores for the female adolescents was 2 (somewhat unacceptable) to 7 (very acceptable) with a mean of 5.3, which equates to self-ratings of a little acceptable. The results for self-ratings of speech acceptability and facial appearance for the male and female subjects are visually displayed in Figures 3 and 4. 


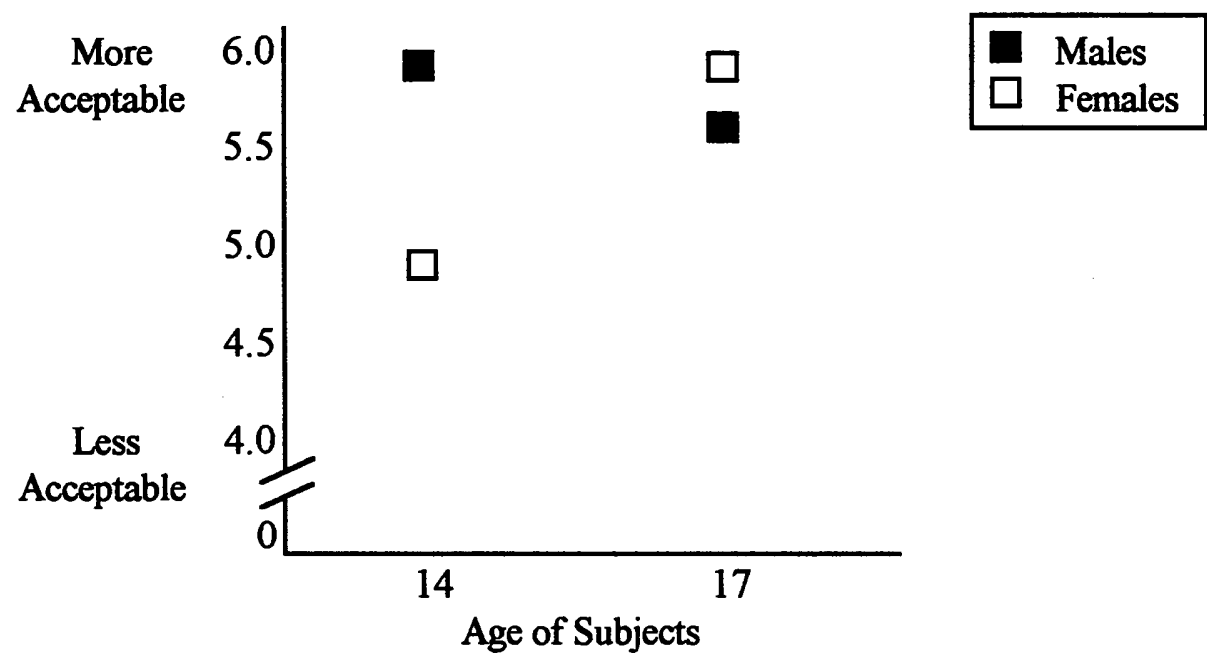

FIGURE 3

SELF-RATING OF FACIAL APPEARANCE MEAN SCORES FOR MALE AND FEMALE GROUPS ACCORDING TO AGE*

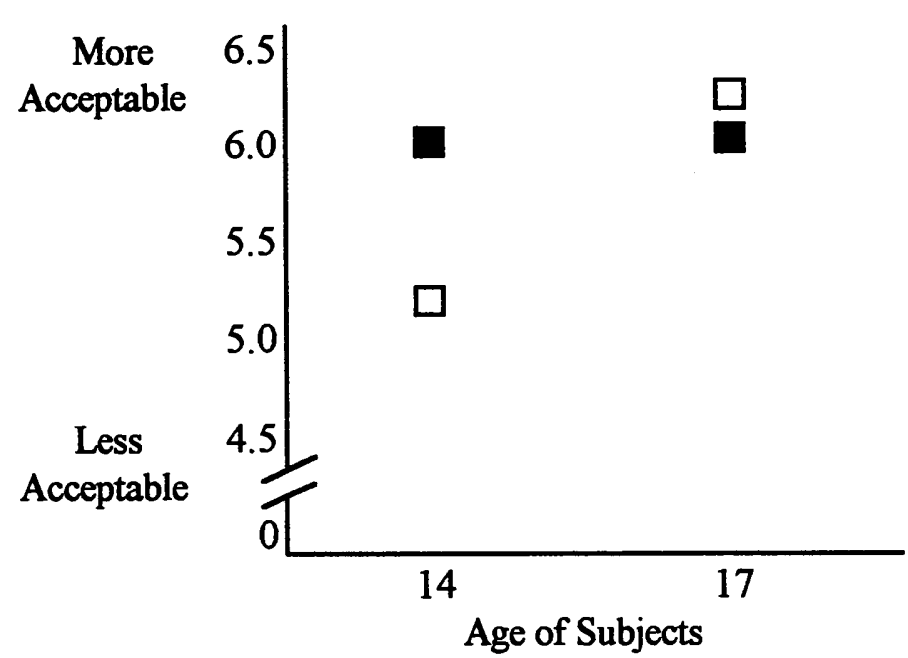

FIGURE 4

SELF-RATING OF SPEECH ACCEPTABILITY MEAN SCORES FOR MALE AND FEMALE GROUPS ACCORDING TO AGE

Note: *Self-ratings of Facial Appearance and Speech Acceptability are reported in numerical form based on the following scale: 1 = very unacceptable, $2=$ somewhat unacceptable, $3=a$ little unacceptable, 4 = equally acceptable and unacceptable, $5=$ a little acceptable, $6=$ somewhat acceptable, 7 = very acceptable. 


\section{Gender Effects on Career Maturity Level}

The first research question asked: Do two age groups of male adolescents with cleft lip and palate (14- and 17-year-olds) differ in level of career maturity as compared to two age groups of female adolescents with cleft lip and palate (14- and 17-year-olds) as measured by a standardized career development test? It was hypothesized that female subjects across age groups would demonstrate higher levels of career maturity. Subject results on the Career Orientation Total (COT) of the CDI were used to respond to this question. Table 4 shows the means for gender COT standard scores. Combined 14- and 17-year-old male subjects received scores ranging from 79 to 127 with a mean of 98.78 ; while combined 14 - and 17 -year-old female subjects received scores ranging from 81 to 144 with a mean of 112.40 . The difference between means on gender for this sample was 13.62 . Table 5 demonstrates comparison of COT standard scores with confidence interval of $95 \%$ for gender comparison.

\section{TABLE 4}

LEAST SQUARES MEANS FOR GENDER ON CAREER ORIENTATION TOTAL STANDARD SCORE $(n=19)$

\begin{tabular}{|c|c|}
\hline Gender & Lease Squares Means \\
\hline Male & 101.14 \\
\hline Female & 112.40 \\
\hline
\end{tabular}


TABLE 5

GENDER COMPARISON TO CAREER ORIENTATION TOTAL STANDARD SCORES WITH CONFIDENCE INTERVALS OF $95 \%(n=19)$

\begin{tabular}{|c|c|c|c|}
\hline $\begin{array}{c}\text { Gender } \\
\text { Comparison }\end{array}$ & $\begin{array}{c}\text { Lower Confidence } \\
\text { Limit }\end{array}$ & $\begin{array}{c}\text { Difference } \\
\text { Between Means }\end{array}$ & $\begin{array}{c}\text { Upper Confidence } \\
\text { Limit }\end{array}$ \\
\hline Males-Females & -.148 & 13.62 & 28.73 \\
\hline
\end{tabular}

\section{Age Effects on Career Maturity Level}

The second research question asked: Do two age groups of male adolescents with cleft lip and palate (14- and 17-year-olds) differ from two age groups of female adolescents with cleft lip and palate (14- and 17-year-olds) in factors thought to be related to career maturity? One factor found in earlier research to influence career maturity level is age, in that career maturity appears to increase with age. It was hypothesized that subjects in the current study would demonstrate this same finding. Tables 6 and 7 show the means for COT standard scores according to age, as well as the differences between the means with a confidence interval of $95 \%$. The data showed that male and female 14 year old adolescents scores ranged of 79 to 115 with mean COT standard score of 99.18 for the 14 year olds participating in this study. The male and female 17 year old adolescents scores ranged from 83 to 144 with a mean COT standard score of 115.25 . The significant difference between the means on the age comparison was 16.07 . 
TABLE 6

Least SQUaRes MEANS For Age on CAREER ORIENTATION TOTAL STANDARD SCORE $(n=19)$

\begin{tabular}{|c|c|}
\hline Age & Least Squares Means \\
\hline 14 & 99.69 \\
\hline 17 & 113.42 \\
\hline
\end{tabular}

\section{TABLE 7}

AgE COMPARISON TO CAREER ORIENTATION TOTAL STANDARD SCORES WITH CONFIDENCE INTERVALS OF $95 \%(n=19)$

\begin{tabular}{|c|c|c|c|}
\hline Age Comparison & $\begin{array}{c}\text { Lower Confidence } \\
\text { Limit }\end{array}$ & $\begin{array}{c}\text { Difference } \\
\text { Between Means }\end{array}$ & $\begin{array}{c}\text { Upper Confidence } \\
\text { Limit }\end{array}$ \\
\hline 14 years -17 years & 0.79 & 16.07 & 31.34 \\
\hline
\end{tabular}

Combined Gender and Age Effects on Career Maturity

A two-way analysis of variance was applied to investigate if there is a differential or interaction effect between gender and age on the measure of career maturity, namely COT standard scores. The results of the ANOVA are shown in Table 8. Similar to earlier literature, age effects were found to be significant $(\mathrm{df}=$ $1, \mathrm{~F}=4.97, p=.04$ with $p<.05$ confidence level). Contrary to past research on career maturity, the effects of gender on career maturity level were not found to be statistically significant $(\mathrm{df}=1, \mathrm{~F}=2.43, p=.14)$. Figure 5 demonstrates, however, that subjects' scores in this study paralleled earlier findings, even if not 
statistically significant, in that females at both age levels scored higher on the measure of career maturity.

\section{TABLE 8}

Two-WAY ANOVA SUMMARY FOR EFFECTS OF AGE AND GENDER ON CAREER ORIENTATION TOTAL STANDARD SCORES $(n=19)$

\begin{tabular}{|l|c|c|c|c|c|}
\hline $\begin{array}{l}\text { Source of } \\
\text { Variation }\end{array}$ & df & $\begin{array}{c}\text { Sum of } \\
\text { Squares }\end{array}$ & $\begin{array}{c}\text { Mean } \\
\text { Square }\end{array}$ & F Value & Significance \\
\hline Age & 1 & 1195.81 & 1195.81 & 4.97 & $0.04^{*}$ \\
\hline Gender & 1 & 583.95 & 583.95 & 2.43 & 0.14 \\
\hline
\end{tabular}

$$
{ }^{*} p<.05
$$

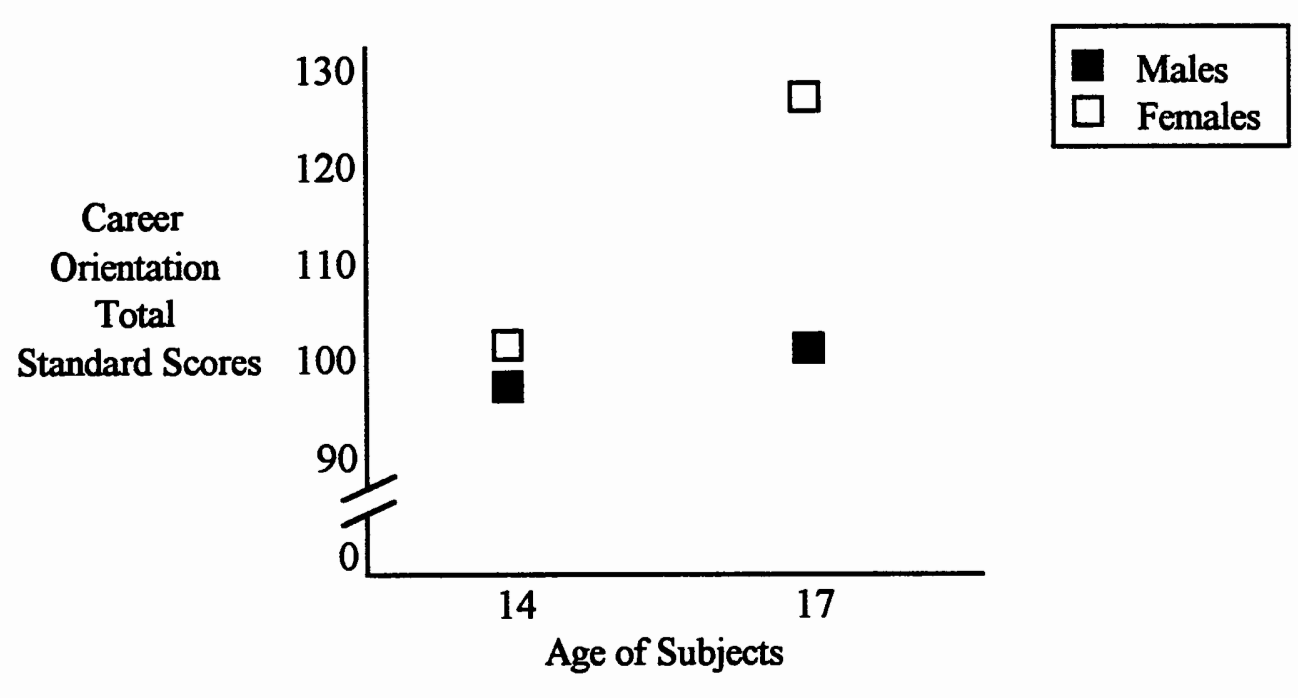

FIGURE 5

Career Orientation Total Mean Standard Scores for Male AND FEMALE GROUPS ACCORDING TO AGE 


\section{Isolated Effects of Other Associated Factors on Career Maturity Level}

The second question this study posed was: Do two age groups of male adolescents with cleft lip and palate (14- and 17-year-olds) differ from two age groups of female adolescents with cleft lip and palate (14- and 17-year-olds) in factors thought to be related to career maturity? Such factors include mental ability, self-concept, self-ratings of speech, and self-ratings of facial appearance. To account for the relatively small sample size, this issue was addressed in two steps. Factors thought to be related to level of career maturity were analyzed with the total sample of male and female adolescents combined to detect which variables demonstrated a significant relationship to level of career maturity. Significant factors were than analyzed for age and gender effects. A Pearson $r$ Correlation Coefficient Analysis was applied to address the relationship between career maturity level and mental ability, career maturity level and self-concept, as well as the relationship between mental ability and self-concept. Table 9 shows the correlation analysis for the three variables used to assess these relationships: COT standard scores as measure of career maturity, SILS Total Score as measure of mental ability, and TSCS Total Positive Score as measure of self-concept. It was hypothesized that a relationship would be found between each of the associated variables and career maturity. Actual results indicated that career maturity as measured by COT scores were moderately correlated to the mental ability as measured by SILS scores $(r=0.56, p=.01)$. The relationship was positive, indicating that high levels of career maturity were 
associated with high levels of mental ability. The relationship between the selfconcept as measured by TSCS and career maturity was relatively weak, as was the relationship between self-concept and mental ability.

A two-way ANOVA was used to further examine the relationship between level of self-concept and level of career maturity using the self-ratings of speech and self-ratings of facial appearance and indicators of self-concept. Tables 10 and 11 show the relationship between career maturity and the self-ratings of speech and facial appearance. Results fail to support the presence of an association between selfratings of facial appearance and career maturity scores, when accounting for the differences due to age. The relationship between the career maturity and self-ratings of speech was also found to be statistically nonsignificant.

TABLE 9

Pearson Correlation Coefficients Between CaReER ORIENTATION TOTAL, MEASURES OF MENTAL ABILITY (SILS), AND

SELF-CONCEPT (TSCS) $(n=19)$

\begin{tabular}{|l|l|l|l|}
\hline & COT & SILS & TSCS \\
\hline COT & & 0.56 & 0.35 \\
$p$-value & & 0.01 & 0.14 \\
\hline SILS & & & 0.19 \\
$p$-value & & & 0.45 \\
\hline TSCS & & & \\
$p$-value & & & \\
\hline
\end{tabular}


TABLE 10

Two-WAY ANOVA SumMaRY FOR EFFECTS OF AGE AND SELF-RATING OF SPEECH ON CAREER ORIENTATION TOTAL STANDARD SCORES $(n=19)$

\begin{tabular}{|l|c|c|c|c|c|}
\hline Source of Variation & df & $\begin{array}{c}\text { Sum of } \\
\text { Squares }\end{array}$ & $\begin{array}{c}\text { Mean } \\
\text { Square }\end{array}$ & $\begin{array}{c}\mathrm{F} \\
\text { Value }\end{array}$ & Significance \\
\hline Age & 1 & 1195.81 & 1195.81 & 5.61 & $0.03^{*}$ \\
\hline Self-Rating of Speech & 6 & 1659.64 & 414.91 & 1.95 & 0.16 \\
\hline
\end{tabular}

${ }^{*} p<.05$.

TABLE 11

TWO-WAY ANOVA SUMMARY FOR EFFECTS OF AGE AND SELF-RATING OF FACIAL APPEARANCE ON CAREER ORIENTATION TOTAL STANDARD SCORES $(n=19)$

\begin{tabular}{|l|c|c|c|c|c|}
\hline Source of Variation & df & $\begin{array}{c}\text { Sum of } \\
\text { Squares }\end{array}$ & $\begin{array}{c}\text { Mean } \\
\text { Square }\end{array}$ & $\begin{array}{c}\mathrm{F} \\
\text { Value }\end{array}$ & Significance \\
\hline Age & 1 & 1195.81 & 1195.81 & 4.97 & $0.04^{*}$ \\
\hline $\begin{array}{l}\text { Self-Rating of Facial } \\
\text { Appearance }\end{array}$ & 4 & 216.50 & 54.13 & 0.17 & 0.95 \\
\hline
\end{tabular}

$$
{ }^{*} p<.05
$$

\section{Interaction Effects on Career Maturity Level}

A two-way ANOVA was completed on the measure of mental ability to see if there was any interaction effect between this measure and age, self-ratings of speech, and self-ratings of facial appearance. A four-factor ANOVA was completed to see if 
there was an interactional relationship between the self-concept and age, gender, self-rating of speech, and self-rating of facial appearance. The results are displayed in Tables 12 and 13. After accounting for differences in age, results failed to find a significant relationship between mental ability and self-ratings of speech and facial appearance. Table 13 shows a statistically significant difference was found between self-concept and age and self-ratings of speech. This finding is related to the fact that self-concept was higher for the 14-year-old group and self-ratings of speech were higher for the 17-year-old group. Figures 2-5 illustrates these relationships between age and overall self-concept as well as for specific judgments of self-rating of speech and facial appearance.

TABLE 12

Two-WAY ANOVA SUMmaRy FoR EFFECTS OF AGE AND SELF-RATING OF SPEECH AND SELF-RATING OF FACIAL APPEARANCE ON SHIPLEY INSTITUTE OF LIVING TOTAL RAW SCORES $(n=19)$

\begin{tabular}{|l|c|c|c|c|c|}
\hline Source of Variation & df & $\begin{array}{c}\text { Sum of } \\
\text { Squares }\end{array}$ & $\begin{array}{c}\text { Mean } \\
\text { Square }\end{array}$ & $\begin{array}{c}\mathrm{F} \\
\text { Value }\end{array}$ & Significance \\
\hline Age & 1 & 174.40 & 174.40 & 3.26 & 0.09 \\
\hline $\begin{array}{l}\text { Self-Rating of Facial } \\
\text { Appearance }\end{array}$ & 4 & 273.24 & 68.31 & 1.28 & 0.33 \\
\hline Age & 1 & 174.40 & 174.40 & 4.16 & 0.06 \\
\hline Self-Rating of Speech & 4 & 423.28 & 105.82 & 2.52 & 0.09 \\
\hline
\end{tabular}


TABLE 13

FOUR-FACTOR ANOVA SUMMARY FOR EFFECTS OF AGE, GENDER, SELF-RATING of FACIAL APPEARANCE, AND SELF-RATING OF SPEECH TENNESSEE SElf-ConcePt SCALE Total Positive Raw SCORES $(n=19)$

\begin{tabular}{|l|c|c|c|c|c|}
\hline Source of Variation & df & $\begin{array}{c}\text { Sum of } \\
\text { Squares }\end{array}$ & $\begin{array}{c}\text { Mean } \\
\text { Square }\end{array}$ & $\begin{array}{c}F \\
\text { Value }\end{array}$ & Significance \\
\hline Age & 1 & 257.38 & 257.38 & 7.52 & $0.03^{*}$ \\
\hline Gender & 1 & 143.82 & 143.82 & 4.20 & 0.08 \\
\hline $\begin{array}{l}\text { Self-Rating of Facial } \\
\text { Appearance }\end{array}$ & 4 & 155.11 & 38.78 & 1.13 & 0.41 \\
\hline Self-Rating of Speech & 4 & 1344.06 & 336.02 & 9.82 & $0.00^{*}$ \\
\hline
\end{tabular}

${ }^{*} p<.05$.

Discussion

Adolescents with cleft lip and palate who participated $\mathrm{n}$ this study across age and gender groups demonstrated at or above average levels of career maturity for the most part. Similarly, the majority of subjects' mental ability, as measured by a standardized test was found to be at or above average compared to their noncleft pears on whom the test was normed. In addition, the majority of subjects' level of positive self-concept, as measured by a standardized test, was found to be at or above average compared to their noncleft peers on whom the test was normed.

Subjects in this study were asked to rate how they thought their speech acceptability and facial appearance was socially acceptable. The 14-year-old female 
adolescents with cleft lip and palate in this study rated their facial appearance, on average, as a little acceptable, as compared to the 17-year-old female subjects in this study who rated their facial appearance, on average, as somewhat acceptable (higher than a little acceptable). The male subjects in this study, across both age groups, rated their facial appearance, on average, as somewhat acceptable. The 14 year-old female subjects rated their speech acceptability, on average, as a little acceptable and the 17-year-old female subjects rated their speech acceptability, on average, as somewhat acceptable. The male subjects, across both age groups, rated their speech acceptability, on average, as somewhat acceptable.

The results of data analysis for the first question posed in this study, Do two age groups of male adolescents with cleft lip and palate (14- and 17-year-olds) differ from two age groups of female adolescents with cleft lip and palate (14- and 17-yearolds) in level of career maturity?, failed to reveal a statistically significant difference between the career maturity of male adolescents and female adolescents with cleft lip and palate. Visual inspection of the data suggests that females displayed higher levels of career maturity than males as demonstrated by a higher range of scores, higher overall group mean score, and consistently higher scores when compared to their chronologically same-aged male peers. When age and gender on career maturity level were analyzed, a statistically significant difference for the age factor was found. Gender effect was not found to be of statistical significance. This was an 
unexpected finding, as both age and gender were expected to contribute statistically to differences in levels of career maturity.

These results are in the same direction of previous research that has demonstrated that females score higher then males on measures of career maturity (Herr \& Enderlein, 1976; McNair \& Brown, 1983; Neely, 1980). It is contrary to previous research that has demonstrated a significant effect for gender and a nonsignificant effect for age within a group of adolescents with and without cleft lip and palate (Letcher-Glembo, 1989). This non-statistical result may be due to the small number of subjects in this study. Another possible explanation, is that there is truly no significant differences between gender and career maturity in the cleft population. Results of past research seem to contradict this hypothesis (Herr \& Enderlein, 1976; Letcher-Glembo, 1989; McNair \& Brown, 1983; Neely, 1980). The finding of a significant effect for age was expected and is similar to past research (Herr \& Enderlein, 1976; Noeth \& Prediger, 1978; Super \& Thompson, 1979).

Limited research has studied the combined effects of age, gender, and other potential life factor conditions such as orofacial clefting, on career maturity level. In Letcher-Glembo's (1989) study with a group of adolescents with and without cleft lip and palate, age effects were found to be statistically significant for female subjects, but not for males. Her findings revealed male subjects demonstrated different levels of career maturity, based on the interaction of age and whether or not they had 
clefts. For the most part, the level of career maturity of noncleft males increased with age while the male subjects with clefts demonstrated levels of career maturity that were more variable across age ranges. Specifically, 17-year-old males with clefts demonstrated a lower mean score on average in terms of career maturity level than the 14-year-old males with clefts tested for in her study. The present study statistically supports age effects for both male and female cleft subject groups.

The second question posed in this study addressed factors thought to be related to career maturity. Factors studied in the present research were mental ability, self-concept, self-rating of speech, and self-rating of facial appearance. Results indicated that there was a moderately positive correlation between level of career maturity and level of mental ability. This finding agrees with previous research results that a relationship exists between career maturity and mental ability (Lawrence \& Brown, 1976; Watson \& Van Aarde, 1986). Results failed to demonstrate a significant correlation between level of career maturity and level of self-concept. Past research has shown that although a correlation exists between level of career maturity and level of self-concept, the strength of this relationship varies. The literature suggests generally that more positive levels of self-concept have been observed in individuals with more advanced levels of career maturity. Although statistically insignificant, this pattern held true in the present study.

In examining the relationship between self-ratings of facial appearance and level of career maturity, this study's results failed to support the presence of an 
association between level of career maturity and perception of the acceptability of one's facial appearance. These results agree with Letcher-Glembo's (1989) study that found self-rating of facial appearance does not contribute significantly to the prediction of one's level of career maturity. The relationship between level of career maturity and self-perception of speech acceptability also was found to be statistically nonsignificant.

The relationships between level of mental ability and self-rating of speech and self-rating of facial appearance was also analyzed. No significant relationship was found among these variables. Level of self-concept and age, gender, and associated self-concept factors were analyzed for an interactional relationship. No significant relationship was found between gender and these variables. A significant correlation was observed between level of self-concept and self-rating of speech. 


\section{CHAPTER V}

\section{SUMMARY AND IMPLICATIONS}

Summary

The purpose of this study was to investigate if there was any difference between two groups of male adolescents with cleft lip and palate (14- and 17-yearolds) and two groups of female adolescents with cleft lip and palate (14- and 17year-olds) in terms of degree of level of career maturity. Subjects who participated completed measures of career maturity, mental ability, and self-concept, and completed self-ratings of speech and facial appearance. The second part of this study looked at the isolated and combined effects of factors thought to be influential on level of career maturity.

Given the limitations of this study, the following is a summary of the results:

1. Adolescents who participated in this study scored at or above age level in terms of career maturity level, mental ability, and overall self-concept, as compared to their chronologically-aged peers without clefts on which standardized tests for each respective construct were normed.

2. Male subjects rated, on average, their speech acceptability and facial appearance to be somewhat acceptable. 
3. Female subjects rate, on average, their speech acceptability and facial appearance to be somewhat acceptable.

4. There is no significant difference between male adolescents with cleft lip and palate and female adolescents with cleft lip and palate in terms of level of career maturity. The consistent pattern in this study was for female subjects to score higher than males at both age levels, however, not to such a degree that it was statistically significant.

5. Age level contributed significantly to level of career maturity; 17year-olds demonstrate a higher level of career maturity than 14-year-olds.

6. The subjects' level of mental ability was moderately correlated with level of career maturity. Specifically, individuals with high mental ability scores demonstrated more advanced levels of career maturity, whereas individuals with lower mental ability scores demonstrated more depressed levels of career maturity.

7. The study failed to find a significant correlation between level of selfconcept and level of career maturity. This lack of a relationship was seen when comparing level of career maturity to scores on an overall measure of self-concept, the TSCS, as well as when focus was given to the relationship between level of career maturity and self-perception of speech acceptability and self-perception of facial appearance. 
Implications

\section{Clinical Implications}

Primary results suggest that populations with cleft lip and palate follow similar patterns in career development as their noncleft peers. The study results can be used as a reassurance by clinicians when counseling families served, that for the most part, it is anticipated their children with cleft lip and palate will follow a similar developmental pattern as their noncleft peers.

Clinicians working with this special population need to be aware of mental ability correlations to career maturity levels. It has been found that correlations exist between mental ability and individuals with cleft palate only, in that these individuals may have depressed levels of mental ability. As the individuals with clefts, namely cleft palate only, as well as those who demonstrate clefting as a component of overall clefting, are susceptible to possible learning disabilities, clinicians need to offer or refer additional services to individuals with cleft lip and palate who display possible learning disabilities (Richman, 1980). Such services might include career counseling, tutoring in areas that impact mental ability, and following these individuals over longer periods of time. It might also encourage the clinician to follow-up on individuals who have discontinued services with a comprehensive cleft lip and palate team, and provide information to families and the adolescent with cleft lip and palate additional reasons to continue services if deemed necessary. 
The data generated in this study suggest that the factors that influence levels of career maturity in the population with cleft lip and palate are similar to those factors that influence their peers who are noncleft. A potential risk factor that needs to be addressed is mental ability. Additional research is needed to account for other important factors that may indicate areas of strength or weakness important to clinical intervention.

\section{Future Research Implications}

This study provided important information about the development of career maturity in two age groups of male and female adolescents with cleft lip and palate indicating that on average, their level of career maturity is similar to the noncleft peers based on available test norms. This suggest that for individuals participating in this study, previous and current support systems such as their family and long-term comprehensive team care have helped them to overcome the potential hurdles imposed by their congenital speech and facial differences. It is this investigators feeling that study findings support the need for early comprehensive intervention for individuals with craniofacial anomalies such as clefting to maximize long-term outcomes. Although level of career maturity was not statistically significantly correlated to gender for this sample, the pattern for female adolescents to mature at a faster rate in terms of career development as compared to their male adolescent counterparts was observed in the current study. This pattern warrants explanation. Further studies could focus on what internal or environmental factors contribute to 
this gender discrepancy tendency. Do cerebral hemispheric differences or hormonal differences in male and females in the adolescent years impact this? Are there social factors, such as differential society interactions between males and females during their critical adolescent years that influence career maturity development? Furthermore, longitudinal evaluation should be employed to determine how this female to male career development process proceeds, and if this wide gap of level of career maturity between male adolescents and female adolescents plateaus or regresses during their adult years in the work force. While this study supports that individuals with clefts display similar levels of career maturity to normative samples of adolescents, it is still unknown how well these effects are maintained when these individuals with persisting facial or speech differences are in real life work situations.

As there is a relationship between level of career maturity and level of mental ability, it would be helpful to explore what specific aspects of mental ability are most contributory to this relationship. This is important, in light of the fact that individuals with craniofacial anomalies are at an increased risk for certain types of learning disabilities (Richman, 1980). If learning disabilities are correlated to depressed levels of mental ability, then select individuals displaying certain types of clefting and concomitant learning disabilities would be at an increased risk of depressed levels of career maturity. Information about more specific impact of mental ability, such as the influence of verbal Intelligence Quotient (IQ) versus 
nonverbal IQ may devise intervention strategies when attempting to promote an individual's level of career maturity. 


\section{REFERENCES}

Adams, G. R. (1978). Physical attractiveness research: Toward a developmental social psychology of beauty. Human Development, 20, 217-323.

Adams, G. R., \& Cohen, A. S. (1974). Characteristics of children and teacher expectancy: An extension to the child's social and family life. Journal of Educational Research, 70, 87-90.

Addington, D. W. (1968). The relationship of selected vocal characteristics to personality perception. Speech Monographs, 35, 472-503.

Benson, P. I., Karabenick, S. A., \& Lerner, R. M. (1976) Pretty pleases: The effects of physical attractiveness, race, and sex on receiving help. Journal of Experimental Psychology, 12, 409-415.

Blood, C. G., \& Hyman, M. (1977). Children's perception of nasal resonance. Journal of Speech and Hearing Disorders, 43, 446-448.

Broder, H. L., Smith, F. B., \& Strauss, R. P. (1994). Effects of visible and invisible orofacial defects on self-perception and adjustment across developmental eras and gender. Cleft Palate Journal, 31, 429-436.

Clifford, M. M., \& Walster, E. (1973). The effect of physical attractiveness on teacher expectations. Sociology of Education, 46, 248-258.

Crites, J. O. (1978). The career maturity inventory. Monterey, CA: CTB/McGraw-Hill.

Dillard, J. M., \& Perrin, D. W. (1980). Puerto Rican, Black, and Anglo adolescents' career aspirations, expectations, and maturity. Vocational Guidance Quarterly, 28, 313-321.

Fitts, W. H. (1965). Tennessee self concept scale manual. Los Angles: Western Psychological Services.

Fitts, W. H. (1991). Tennessee self concept scale. Los Angles: Western Psychological Services. 
Glass, L. (1978). The effects of cosmetic appearance and speech on patients with orofacial anomalies. Unpublished doctoral dissertation, University of Minnesota.

Harper, D. C., \& Richman, L. C. (1978). Personality profiles of physically impaired adolescents. Journal of Clinical Psychology, 34, 636-642.

Herr, E. L., \& Cramer, S. H. (1984). Career guidance and counseling through the life span (2nd ed.). Boston: Little, Brown, \& Company.

Herr, E. L., \& Enderlein, T. (1976). Vocational maturity: The effects of school, grade, curriculum, and sex. Journal of Vocational Behavior, 8, 227-238.

Hildebrandt, K. A., \& Fitzgerald, H. F. (1978). Adults' responses to infants varying in perceived cuteness. Behavioral Processes, 3, 159-172.

Holland, M. (1981). Relationships between vocational development and selfconcept in sixth grade students. Journal of Vocational Behavior, 18, 228-236.

Jones, O. M., Hansen, J. C., \& Putnam, B. A. (1976). Relationship of selfconcept and vocational maturity to vocational preferences of adolescents. Journal of Vocational Behavior, 8, 31-40.

Jordaan, J. P., \& Heyde, M. B. (1979). Vocational maturity in the high school years. New York: Teachers College Press.

Kapp, K. (1979). Self-concept of the cleft lip and/or palate child. Cleft Palate Journal, 26, 171-176.

Karayani, M. (1981). Career maturity of emotionally maladjusted high school students. Vocational Guidance Quarterly, 29(3), 213-220.

Lawrence, W., \& Brown, D. (1976). An investigation of intelligence, selfconcept, socioeconomic status, race, and sex as predictors of career maturity. Journal of Vocational Behavior, 9, 43-52.

Letcher-Glembo, L. (1989). The career maturity of adolescents with clefts. Unpublished doctoral dissertation, University of Minnesota.

McNair, D., \& Brown, D. (1983). Predicting the occupational aspirations, occupational expectations, and career maturity of black and white male and female 10th graders. Vocational Guidance Quarterly, 32, 29-36. 
Moller, K. T. (1993). Interdisciplinary team approach: Issues and procedures. In D. T. Moller \& C. D. Starr (Eds.), Cleft palate: Interdisciplinary issues and treatment (pp. 1-24). Austin, TX: PRO-ED, Inc.

Mori, A. A. (1982). Career attitudes and job knowledge among junior high school regular, special, and academically talented students. Career Development for Exceptional Individuals, 5, 62-69.

Mowrer, D. E., Wahl, P., \& Doolan, S. J. (1978). Effect of lisping on audience evaluation of male speakers. Journal of Speech and Hearing Disorders, 43(2), 140-148.

Neely, M. A. (1980). Career maturity inventory interpretations for grade 9 boys and girls. Vocational Guidance Quarterly, 29(2), 113-124.

Noeth, R. J., \& Prediger, D. J. (1978). Career development over the high school years. Vocational Guidance Quarterly, 26, 244-254.

Paulson, M. J., \& Lin, T. (1970). Predicting WAIS IQ from SILS Harford Scores. Journal of Clinical Psychology, 26, 453-461.

Pavlak, M. F., \& Krammer, P. P. (1985). The effects of a career guidance program on the career maturity and self-concept of delinquent youth. Journal of Vocational Behavior, 26, 41-54.

Penner, S. G., Belander, S. A., \& Starr, C. D. (1978). Occupational acceptability and nasality. Human Communication, 16, 181-185.

Pound, R. E. (1978). Using self-concept subscales in predicting career maturity for race and sex subgroups. Vocational Guidance Quarterly, 27, 61-70.

Richman, L. C. (1976). Behavior and achievement of cleft palate children. Cleft Palate Journal, 13, 4-10.

Richman, L. C. (1980). Cognitive patterns and learning disabilities in cleft palate children with verbal deficits. Journal of Speech and Hearing Research, 23, 447-456.

Richman, L. C. (1983). Self-reported social, speech, facial concerns, and personality adjustment of adolescents with cleft lip and palate. Cleft Palate Journal, 20, 108-112. 
Richman, L. C., \& Eliason, M. J. (1986). Development in children with cleft lip and/or palate: Intellectual, cognitive, personality, and parental factors. Seminars in Speech and Language, 7(3), 225-239.

Richman, L. C., Holmes, C. S., \& Eliason, M. (1985). Adolescents with cleft lip and palate: Self-perceptions of appearance and behavior related to personality adjustment. Cleft Palate Journal, 22, 93-96.

Schneiderman, C. R., \& Auer, L. E. (1984). The behavior of the child with cleft lip and palate as perceived by parents and teachers. Cleft Palate Journal, 21(3), 224-228.

Schneiderman, C. R., \& Harding, M. A. (1984). Social ratings of children with cleft lip by school peers. Cleft Palate Journal, 21(3), 219-223.

Seligman, L. (1980). Assessment in developmental career counseling. Cranston, RI: Carroll Press.

Shipley, W. C. (1940). A self-administering scale for measuring intellectual impairment and deterioration. Journal of Psychology, 9, 371-377.

Sinko, G. R., \& Hedrick, D. L. (1982). The interrelationships between ratings of speech and facial acceptability in persons with cleft palate. Journal of Speech and Hearing Research, 25, 402-407.

Super, D. E. (1953). A theory of vocational development. American Psychologist, 8, 185-190.

Super, D. E. (1957). The psychology of careers. New York: Harper \& Row.

Super, D. E., \& Overstreet, P. L. (1960). Vocational maturity of ninth grade boys. New York: Teachers College Press.

Super, D. E., \& Thompson, A. S. (1979). A six-scale, two-factor measure of adolescent career or vocational maturity. Vocational Guidance Quarterly, 28, 6-15.

Thompson, A. S., Lindeman, R. H., Super, D. E., Jordaan, J. P., \& Meyers, R. A. (1981). Career development inventory vol. 1: Technical manual. Palo Alto, CA: Consulting Psychologists Press, Inc. 
Thompson, A. S., Lindeman, R. H., Super, D. E., Jordaan, J. P., \& Meyers, R. A. (1984). Career development inventory vol. 2: Technical manual. Palo Alto, CA: Consulting Psychologists Press, Inc.

Tobiasen, J. M. (1984). Psychosocial correlates of congenital facial clefts: A conceptualization and model. Cleft Palate Journal, 21(3), 131-138.

Tobiasen, J. M. (1987). Social judgments of facial deformity. Cleft Palate Journal, 24(4), 323-327.

Walsh, J. A. (1984). Review of Tennessee self concept scale. In D. J. Keyser \& R. C. Sweetland (Eds.), Test critiques (vol. 4). Kansas City, MO: Test Corporation of America.

Watson, M. B., \& Van Aarde, J. A. (1986). Attitudinal career maturity of south African colored high school pupils. Journal of Vocational Behavior, 29, 7-16.

Westbrook, B. W., Sanford, E. E., O'Neal, P., Horne, D. F., Fleenor, J., \& Garren, R. (1985). Predictive and construct validity of six experimental measures of career maturity. Journal of Vocational Behavior, 27, 338-355.

Zachary, R. A. (1987). Shipley institute of living scale: Revised manual. Los Angeles: Western Psychological Services.

Zunker, V. G. (1990). Career counseling: Applied concepts of life planning (3rd ed.). Monterey, CA: Brooks/Cole Publishing Company. 
APPENDIX A

CONSENT FORM FOR

KAISER PERMANENTE SUBJECTS 


\section{CONSENT FORM}

TITLE: Effects of Orofacial Clefts on Early Career Development PRINCIPAL INVESTIGATOR: Lisa Letcher-Glembo, Ph.D. (503) 725-8378 PURPOSE: I have been invited to participate in this research study because I am within the ages of 14 to 21 years of age. The purpose of this study is to determine the way teenagers and young adults decide on their future careers. We are particularly interested in knowing how persons seen in our clinics go about the task. We need to obtain this information so that we can determine if we should develop programs to assist persons in making their career decisions. To participate in this project, I will need to be seen one time only for approximately a 1 to 2 hour time period. Lisa Letcher-Glembo, the Principal Investigator, could come to my home at my convenience for this to be completed even if it is far outside of the Portland metropolitan area.

PROCEDURES: As previously stated, she needs to see me on only one occasion for about one to two hours of my time. During that time, I will fill out some questionnaires, take some tests, make a recording, and have a picture taken. The questionnaires and tests will be used to determine how I am pursuing my career goals, my general intellectual skills, and how I perceive myself. The recording and picture will be used to describe my appearance and speech. The recording and picture will by destroyed at the end of the study. 
RISKS AND DISCOMFORTS: There are no foreseeable risks or discomforts anticipated from my participation with the exception of the potential inconvenience of time. In fact, individuals who have participated thus far have commented how they enjoyed learning more about themselves and their own career interests.

BENEFITS: She will furnish a detailed report regarding the career development information obtained during my evaluation. It should be noted that results will not be available at the time of my evaluation. These will be mailed to me following my participation. I will be informed of new developments during the course of this study if they indicate a significant risk for my participation.

CONFIDENTIALITY: Any information obtained will be kept strictly confidential and disclosed only with my permission. I will not be identified in any written reports or publications that result form this study.

COSTS: There will be no cost to my to participate in the project. The results of the career development testing will be completed and sent to me following my participation free of charge as our way of saying "thanks" for participating. I will not be directly reimbursed for my participation in this study.

PARTICIPATION: I understand that, because of this study, I may experience an inconvenience of time commitment. Participation in this study will require a one time only time commitment of approximately 2 hours.

I will not be paid for my participation.

I understand that I may receive personal benefit from the career development testing and that other individuals may benefit from the results of this study. 
Lisa Letcher-Glembo [(5030 725-8378], principal researcher, has offered to answer any questions I have about the study and what I am expected to do. I understand that I may call her collect or she will return my call if the call to Portland is long distance.

I have been promised that all information I give will be kept confidential to the extent permitted by law, and that the names of all people in the study will remain anonymous.

I understand that I do not have to take part in this study and that refusal or agreement to participate will no affect my relationship with or treatment at Portland State University nor Kaiser Permanente. I understand that I will receive a copy of this form for my own records.

My signature below, unless noted otherwise, indicates that I have read the above information and agree to participate in the study. I will receive a call to schedule a visit to have the career development testing completed upon mailing in the attached consent form.

Signature of participant between the ages of 14 through 17 years of age

Signature of Parent 
Please complete this portion and return it in the included self-addressed stamped envelope to Lisa Letcher-Glembo, Ph.D., Portland State University, P.O. Box 751, Portland, Oregon, 97207-0751.

NAME:

ADDRESS:

DATE OF BIRTH:

PHONE:

DYes, I wish to participate in this project

$\square$ No, I do not wish to participate in this project

$\square$ I, would like more information about this project prior to agreeing to participate.

Please contact me in the following way:

Name

Relationship to Requested Participant

If you have any questions about this research, you rights and responsibilities as a research subject, or about research related-injuries, you may contact Mary

Durham, Ph.D., Vice President for Research, Kaiser Foundation Hospitals, 3352400. 


\section{APPENDIX B}

\section{COVER LETTER FOR OREGON HEALTH}

SCIENCES UNIVERSITY SUBJECTS 
February 17, 1997

John and Jane Smith

999 Nowhere Street

Portland, OR 00000

Dear (Addressed to adolescent and parents or to young adult with cleft lip and palate):

I would like to inform you of a study that is underway regarding how teenagers and young adults decide on their future careers. I am not personally conducting this study, but have reviewed the study and feel that results may contribute to the care of individuals with clefting. I am not currently receiving a fee for my referral of your child to this study. If this project is federally funded, my department and I will be receiving a fee for our referral of your child to this study for time spent in subject identification. I will be listed as author in any publication that results as a part of this study.

The study is interested in knowing how adolescents and young adults seen in our clinics go about their career development. Results of a study such as this can help us serve you better by determining if programs should be developed to provide assistance with the career development process. I will not be reviewing individual subjects' results, but at your signed request, the principal investigator, Dr. Letcher-Glembo, has assured me that results could be shared with me if you wish. You personally will be receiving a complete report of test results following participation in the study.

Attached you will find information and a consent form about the study. Please read through the documents and return pages 3 and 4 in a timely fashion either indicating your desire to participate, desire not to, or your request for additional information. Dr. Letcher-Glembo, who is leading the project, has provided her phone number, (503) 725-8378 and can answer any questions you may have. You may call her collect if you are calling outside of the Portland Metropolitan area. Please note that if you decide to participate or decide to participate and then decide to drop out, it will not effect the relationship you have with our clinic. Furthermore, if you have any questions regarding your child's rights as a research subject, you may contact the Oregon Health Sciences University Institutional Review Board at (503) 494-7887.

Sincerely yours,

Janet Brockman, M.S., CCC-SLP

Director, Craniofacial Disorders Program

Child Development and Rehabilitation Center 


\section{APPENDIX C}

\section{CONSENT FORM FOR OREGON HEALTH}

SCIENCES UNIVERSITY SUBJECTS 


\section{CONSENT FORM}

TITLE: Effects of Orofacial Clefts on Early Career Development

PRINCIPAL INVESTIGATOR: Lisa Letcher-Glembo, Ph.D. (503) 725-8378

PURPOSE: Your have been invited to participate in this research study because you are within the ages of 14 to 21 years of age. The purpose of this study is to determine the way teenagers and young adults decide on their future careers. We are particularly interested in knowing how persons seen in our clinics go about the task. We need to obtain this information so that we can determine if we should develop programs to assist persons in making their career decisions. To participate in this project, you would need to be seen one time only for approximately a 1 to 2 hour time period. Lisa Letcher-Glembo, the Principal Investigator, could come to your home at your convenience for this to be completed even if it is far outside of the Portland metropolitan area.

\section{PROCEDURES:}

As previously stated, she needs to see you on only one occasion for about one to two hours of your time. During that time, you will fill out some questionnaires, take some tests, make a recording, and have a picture taken. The questionnaires and tests will be used to determine how you are pursuing your career goals, your general intellectual skills, and how you perceive yourself. The recording and picture will be used to describe your appearance and speech. The recording and picture will be destroyed at the end of the study. 


\section{RISKS AND DISCOMFORTS:}

There are no foreseeable risks or discomforts anticipated from your participation with the exception of the potential inconvenience of time. In fact, individuals who have participated thus far have commented how they enjoyed learning more about themselves and their own career interests.

\section{BENEFITS:}

She will furnish a detailed report regarding the career development information obtained during your evaluation. It should be noted that results will not be available at the time of your evaluation. These will be mailed to you following your participation. You will be informed of new developments during the course of this study if they indicate a significant increased risk for your participation.

\section{CONFIDENTIALITY:}

Any information obtained will be kept strictly confidential and disclosed only with your permission. You will not be identified in any written reports or publications that result from this study.

\section{COSTS:}

There will be no cost to you to participate in the project. The results of the career development testing will be completed and sent to you following your participation free of charge as our way of saying "thanks" for participating. You will not be directly reimbursed for your participation in this study. 


\section{LIABILITY:}

There are no invasive procedures completed as part of participation in this study; however, it is noted that it is the policy of the U.S. Department of Health and Human Services, or any federal agency funding research projects to compensate or provide medical treatment for human subjects in the event the research results in physical injury. The Oregon Health Sciences University, as a public corporation, is subject to the Oregon Tort Claims Act, and is self-insured for liability claims. If you suffer any injury from this research project, compensation would be available to you only if you establish that the injury occurred through the fault of the University, its officers, or employees. If you have further questions regarding liability, please call the Medical Services Director at (503) 494-8014.

\section{PARTICIPATION:}

I understand that, because of this study, I may experience an inconvenience of time commitment.

Participation in this study will require a one time only time commitment of approximately 2 hours.

I will not be paid for my participation.

I understand that I may receive personal benefit from the career development testing and that other individuals may benefit from the results of this study.

Lisa Letcher-Glembo [(503) 725-8378], principal researcher, has offered to answer any questions I have about the study and what I am expected to do. I 
understand that I may call her collect or she will return my call if the call to Portland is long distance. If I have any questions regarding my rights as a research subject, I understand that I may contact the Oregon Health Sciences University Institutional Review Board at (503) 494-7887.

I have been promised that all information I give will be kept confidential to the extent permitted by law, and that the names of all people in the study will remain anonymous.

I understand that I do not have to take part in this study and that refusal or agreement to participate will not affect my relationship with or treatment at Portland State University nor Oregon Health Sciences University. I understand that I may withdraw from the study at any time.

I understand that I will receive a copy of this form for my records.

Your signature below, unless noted otherwise, indicates that you have read the above information and agree to participate in the study. You will receive a call to schedule a visit to have the career development testing completed upon mailing in the attached consent form. 
Please complete this portion and return it in the included self-addressed stamped envelope to Lisa Letcher-Glembo, Ph.D., Portland State University, P.O. Box 751, Portland, Oregon, 97207-0751.

NAME:

ADDRESS:

DATE OF BIRTH:

PHONE:

$\square$ Yes, I wish to participate in this project

$\square$ No, I do not wish to participate in this project

$\square$ I, would like more information about this project prior to agreeing to participate.

Please contact me in the following way: 
APPENDIX D

BIOGRAPHICAL QUESTIONNAIRE 
Biographical Questionnaire

1. Are you a male or a female? $\square$ Male $\square$ Female

2. What grade are you in school? $\square 9^{\text {th }}$ grade $\square 10^{\text {th }}$ grade

$\square 11^{\text {th }}$ grade $\square 12^{\text {th }}$ grade

3. How many brothers and sisters do you have?

4. If you do have brothers and sisters, what are their ages?

5. At this point in time, what occupation do you think you would most likely to pursue in the future?

6. What type and how many years of schooling beyond high school do you think that you will complete?

$\square$ No further schooling

$\square$ Vocational/technical school certificate

2-year Associate of Arts (Community College)

$\square$ 4-year Bachelor's Degree

Master's Degree

$\square$ Doctorate Degree (Ph.D.)

$\square$ Other

7. What is your father's occupation?

8. What type and how many years of schooling beyond high school did your father complete?

$\square$ No further schooling

$\square$ Vocational/technical school certificate

12-year Associate of Arts (Community College)

$\square$ 4-year Bachelor's Degree

$\square$ Master's Degree

$\square$ Doctorate Degree (Ph.D.)

Dother 
9. What is your mother's occupation?

10. What type and how many years of schooling beyond high school did your mother complete?

$\square$ No further schooling

$\square$ Vocational/technical school certificate

$\square$ 2-year Associate of Arts (Community College)

$\square$ 4-year Bachelor's Degree

$\square$ Master's Degree

Doctorate Degree (Ph.D.)

Dother

11. Which of the following type dwellings do you live in?
$\square$ Apartment
$\square$ House
DTownhouse

$\square$ Condominium

DOther

12. Does your family own or rent your home?

$\square$ Rent

Down

DOther

13. Which of the following items does your family own?

$\square$ Microwave $\square$ Boat $\square$ VCR

$\square$ Summer house $\quad \square$ Color television

14. How many cars does your family own?

15. Have you ever taken a trip outside of the United States? $\square$ Yes $\square$ No

16. If the answer to Question 15 is yes, how many times and where?

17. If you had to guess, what social class do you think your family falls into? DUpper Class $\square$ Middle Class $\square$ Lower Class

18. Have you ever received treatment for speech? $\quad$ YYes $\square$ No If yes, how many years did you receive treatment for speech?

19. Are you receiving treatment for speech now?

20. What is your current city and state of residence? 


\section{APPENDIX E}

\section{SELF-RATINGS OF SPEECH AND}

FACIAL APPEARANCE 


\section{SELF-RATINGS OF SPEECH}

\begin{tabular}{|c|c|c|c|c|c|c|}
\hline $\begin{array}{c}\text { Very } \\
\text { Unacceptable }\end{array}$ & $\begin{array}{l}\text { Somewhat } \\
\text { Unacceptable }\end{array}$ & $\begin{array}{c}\text { A Little } \\
\text { Unacceptable }\end{array}$ & $\begin{array}{c}\text { Equally } \\
\text { Acceptable } \\
\text { and } \\
\text { Unacceptable } \\
\text { (Neither } \\
\text { Acceptable } \\
\text { nor } \\
\text { Unacceptable) }\end{array}$ & $\begin{array}{c}\text { A Little } \\
\text { Acceptable }\end{array}$ & $\begin{array}{l}\text { Somewhat } \\
\text { Acceptable }\end{array}$ & $\begin{array}{c}\text { Very } \\
\text { Acceptable }\end{array}$ \\
\hline
\end{tabular}

SELF-RATINGS OF FACIAL APPEARANCE

\begin{tabular}{|c|c|c|c|c|c|c|}
\hline $\begin{array}{c}\text { Very } \\
\text { Unacceptable }\end{array}$ & $\begin{array}{c}\text { Somewhat } \\
\text { Unacceptable }\end{array}$ & $\begin{array}{c}\text { A Little } \\
\text { Unacceptable }\end{array}$ & $\begin{array}{c}\text { Equally } \\
\text { Acceptable } \\
\text { and } \\
\text { Unacceptable } \\
\text { (Neither } \\
\text { Acceptable } \\
\text { nor } \\
\text { Unacceptable) }\end{array}$ & $\begin{array}{c}\text { A Little } \\
\text { Acceptable }\end{array}$ & $\begin{array}{l}\text { Somewhat } \\
\text { Acceptable }\end{array}$ & $\begin{array}{c}\text { Very } \\
\text { Acceptable }\end{array}$ \\
\hline
\end{tabular}




\section{APPENDIX F}

\section{LAZY JACK READING PASSAGE}




\section{LAZY JACK}

Once upon a time there was a boy named Jack. He lived in a red house with a white roof. His mother worked hard each day feeding the pigs and the chickens or washing clothes in a big tub. But all Jack did was to play with the squirrels or sit in a chair by the stove and sleep. In the summer Jack liked very much to drink cold milk or eat ice-cream under a shady tree. Some days he would visit the zoo to see the animals and some days he would go to a large river to fish. But when winter came he often stayed at home to play with his bicycle, his blocks, his toy soldiers, or his yellow wagon and sometimes he just sat watching the other children skate on the smooth ice. But if anybody mentioned work, nothing could make him leave his place before the warm fire. As usual, he thought only of his own pleasure. 